\title{
Review Article \\ Redox Homeostasis and Cellular Antioxidant Systems: Crucial Players in Cancer Growth and Therapy
}

\author{
Barbara Marengo, ${ }^{1}$ Mariapaola Nitti, ${ }^{1}$ Anna Lisa Furfaro, ${ }^{2}$ Renata Colla, ${ }^{1}$ \\ Chiara De Ciucis, ${ }^{1}$ Umberto Maria Marinari, ${ }^{1}$ Maria Adelaide Pronzato, ${ }^{1}$ \\ Nicola Traverso, ${ }^{1}$ and Cinzia Domenicotti ${ }^{1}$ \\ ${ }^{1}$ Department of Experimental Medicine, General Pathology Section, University of Genova, 16132 Genova, Italy \\ ${ }^{2}$ Giannina Gaslini Institute, Genova, Italy
}

Correspondence should be addressed to Cinzia Domenicotti; cinzia.domenicotti@unige.it

Received 18 March 2016; Accepted 18 May 2016

Academic Editor: Tetsuro Kamiya

Copyright (C) 2016 Barbara Marengo et al. This is an open access article distributed under the Creative Commons Attribution License, which permits unrestricted use, distribution, and reproduction in any medium, provided the original work is properly cited.

\begin{abstract}
Reactive oxygen species (ROS) and their products are components of cell signaling pathways and play important roles in cellular physiology and pathophysiology. Under physiological conditions, cells control ROS levels by the use of scavenging systems such as superoxide dismutases, peroxiredoxins, and glutathione that balance ROS generation and elimination. Under oxidative stress conditions, excessive ROS can damage cellular proteins, lipids, and DNA, leading to cell damage that may contribute to carcinogenesis. Several studies have shown that cancer cells display an adaptive response to oxidative stress by increasing expression of antioxidant enzymes and molecules. As a double-edged sword, ROS influence signaling pathways determining beneficial or detrimental outcomes in cancer therapy. In this review, we address the role of redox homeostasis in cancer growth and therapy and examine the current literature regarding the redox regulatory systems that become upregulated in cancer and their role in promoting tumor progression and resistance to chemotherapy.
\end{abstract}

\section{Pathophysiology of Reactive Oxygen Species and Antioxidant Defenses}

Reactive oxygen species (ROS) are highly reactive molecules that are principally derived from the oxygen that is consumed in various metabolic reactions occurring mainly in the mitochondria, peroxisomes, and the endoplasmic reticulum. ROS include the superoxide anion $\left(\mathrm{O}_{2}{ }^{-}\right)$and hydroxyl radicals $\left(\mathrm{OH}^{*}\right)$ as well as nonradical molecules such as hydrogen peroxide $\left(\mathrm{H}_{2} \mathrm{O}_{2}\right)$ [1]. $\mathrm{H}_{2} \mathrm{O}_{2}$ is the more stable and diffusible form of ROS, it is selectively reactive towards cysteine residues on proteins, and, in the low nanomolar range, it can control cellular signaling (Figure 1).

ROS are mainly produced by the mitochondrial respiratory chain and also by enzyme-catalyzed reactions involving NADPH oxidase (NOX), xanthine oxidase, nitric oxide synthase (NOS), arachidonic acid, and metabolizing enzymes such as the cytochrome P450 enzymes, lipoxygenase, and cyclooxygenase [2] (Figure 1).
The modulation of intracellular ROS levels is crucial for cellular homeostasis, and different ROS levels can induce different biological responses. At low and moderate levels ROS can act as signaling molecules that sustain cellular proliferation and differentiation and activate stressresponsive survival pathways [3]. For instance, ROS can stimulate the phosphorylation of protein kinase $\mathrm{C}$ (PKC), p38 mitogen-activated protein kinase (p38 MAPK), extracellular signal-regulated kinase (ERK)1/2, phosphoinositide 3kinase/serine-threonine kinase (PI3K/Akt), protein kinase B (PKB), and JUN N-terminal kinase (JNK) [4-6]. ROS are also involved in the increased expression of antioxidant genes related to the activation of transcription factors such as the nuclear factor erythroid 2-related factor 2 (Nrf2), activator protein 1 (AP-1), nuclear factor $\kappa \mathrm{B}(\mathrm{NF}-\kappa \mathrm{B})$, hypoxiainducible transcription factor la (HIF-1a), and p53 [7-9].

At high levels, ROS promote severe cell damage and death. Cancer cells display elevated ROS compared to normal counterparts as the result of the accumulation of intrinsic 


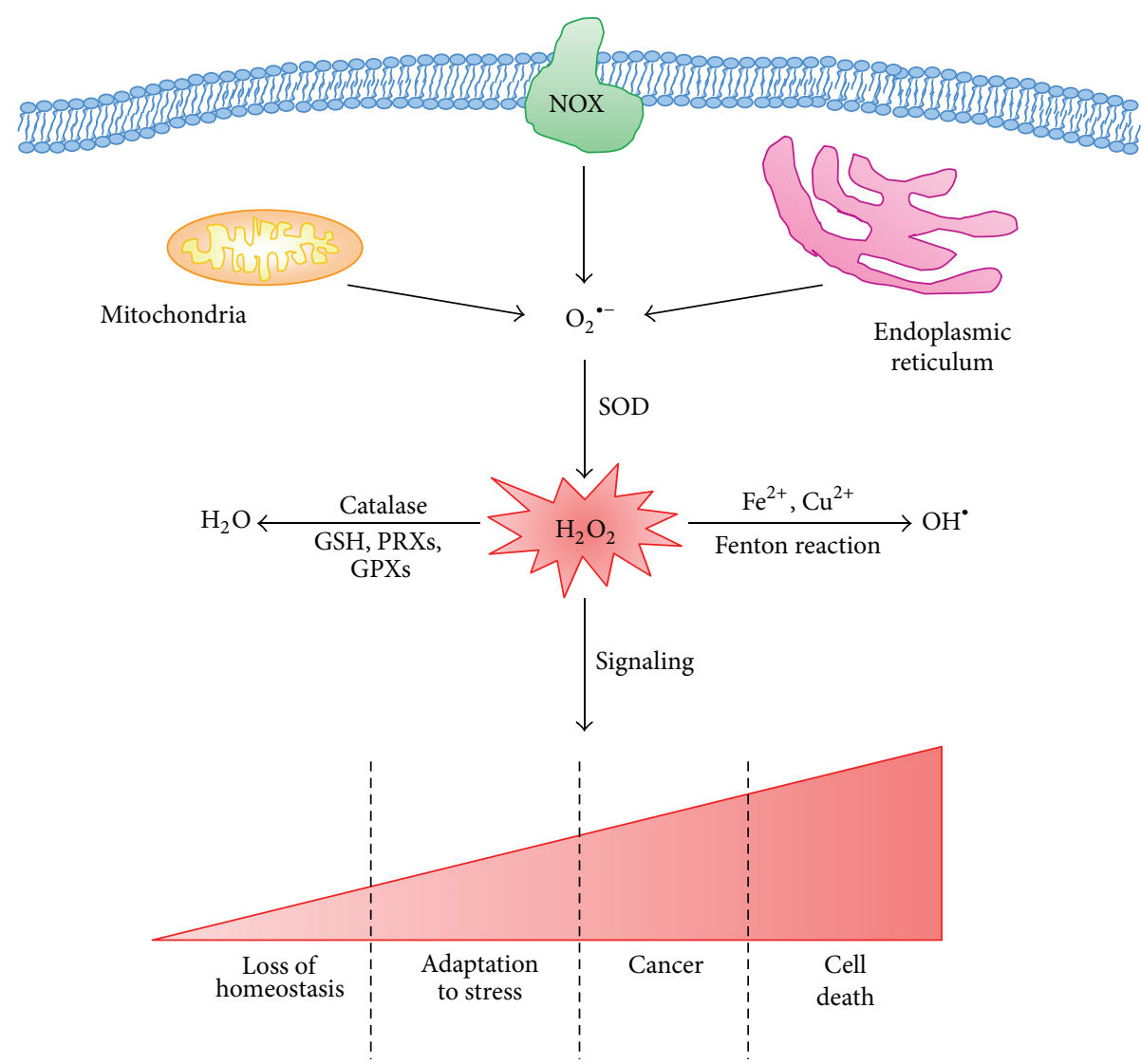

FIGURE 1: Redox homeostasis is a balance of ROS generation and elimination. Mitochondria, NAPH oxidase (NOX), and endoplasmic reticulum are the three major intracellular sources of ROS. Anion superoxide $\left(\mathrm{O}_{2}{ }^{--}\right)$is the principal form of ROS and can be rapidly converted into hydrogen peroxide $\left(\mathrm{H}_{2} \mathrm{O}_{2}\right)$ by superoxide dismutase (SOD). $\mathrm{H}_{2} \mathrm{O}_{2}$ can be catalyzed to hydroxyl radical $\left(\mathrm{OH}^{*}\right)$ in the presence of Fe ${ }^{2+}$ or $\mathrm{Cu}^{2+}$ ions or be converted to $\mathrm{H}_{2} \mathrm{O}$ by catalase. The amount of $\mathrm{H}_{2} \mathrm{O}_{2}$ is decisive for the cell fate: low and intermediate levels of the peroxide stimulate loss of cell homeostasis and increased adaptation to stress leading to neoplastic transformation while high levels induce cell death.

and/or environmental factors. The more relevant factors include hypoxia, enhanced cellular metabolic activity, mitochondrial dysfunction, oncogene activity, increased activity of oxidases, lipoxygenases and cyclooxygenases, and the cross talk between cancer cells and immune cells recruited to the tumor site. Recent research has revealed that conditions inducing oxidative stress lead the neoplastic cells to develop powerful antioxidant mechanisms.

Several types of antioxidants play important roles in ROS homeostasis, including dietary natural antioxidants (e.g., vitamins $\mathrm{A}, \mathrm{C}$, and $\mathrm{E}$ ), endogenous antioxidant enzymes (e.g., superoxide dismutase, catalase, glutathione peroxidase, glutathione reductase, and peroxiredoxins), and antioxidant molecules (e.g., glutathione, coenzyme Q, ferritin, and bilirubin).

Superoxide Dismutases. Superoxide dismutases (SOD) were the first characterized antioxidant enzymes [10] able to dismutate two $\mathrm{O}_{2}{ }^{--}$anions into $\mathrm{H}_{2} \mathrm{O}_{2}$ and molecular oxygen. Three different types of SOD are expressed in human cells: copper-zinc SOD (CuZnSOD), which is present mainly in the cytoplasm, manganese SOD (MnSOD), located in the mitochondria, and extracellular SOD. It has been demonstrated that mice lacking MnSOD produce a massive oxidative stress and die perinatally [11] while CuZnSOD-deficient mice have persistent oxidative damage and develop hepatocellular carcinoma [12]. In addition, a variant allele of MnSOD has been associated with an elevated risk of prostate [13], lung [14], ovarian cancers [15], and non-Hodgkin's lymphoma [16].

Catalase. Catalase, a heme enzyme that catalyzes the reaction that converts two molecules of $\mathrm{H}_{2} \mathrm{O}_{2}$ to $\mathrm{O}_{2}$ and two molecules of $\mathrm{H}_{2} \mathrm{O}$, is responsible for the detoxification of various phenols, alcohols, and hydrogen peroxide. Several epidemiologic studies have investigated the relationship between the mutations of catalase and human cancer but the results obtained are contradictory. In fact, a decreased catalase activity has been found both in blood samples and in tissues of breast cancer patients $[17,18]$ and in oral and pancreatic carcinomas $[19,20]$. However, an increase in catalase levels has been reported in breast cancer tissue [21], malignant mesothelioma, and colorectal carcinoma $[22,23]$.

Peroxiredoxins. Peroxiredoxins (PRDXs) are a family of six isoenzymes able to reduce alkyl hydroperoxides and $\mathrm{H}_{2} \mathrm{O}_{2}$ to their corresponding alcohol or $\mathrm{H}_{2} \mathrm{O}$. PRDXs are considered to 
be amongst the most important antioxidant enzymes, known to balance the production of cellular $\mathrm{H}_{2} \mathrm{O}_{2}$ which is essential for cell signaling and metabolism [24]. Under oxidative stress conditions, PRDXs are upregulated by Nrf2 activity and several studies have shown that the overexpression of PRDXs could either inhibit the development of cancer or promote growth of cancers [25].

In fact, PRDX1 interacts with the c-Myc oncogene and suppresses its transcriptional activity playing a tumorsuppressive role in breast cancer development [26, 27]. On the contrary, PRDX1 is associated with the promotion of oral, esophageal, lung, hepatocellular, and pancreatic carcinoma by upregulating heme oxygenase 1 and activating the NF- $\kappa \mathrm{B}$ pathway [28-31]. Moreover, also PRDX2 promotes colorectal carcinoma through upregulation of $\mathrm{Wnt} / \beta$ catenin and prostate cancer through upregulation of androgen receptor activity [32,33]. Furthermore, several studies have demonstrated that the overexpression of PRDX1, PRDX2, and PRDX3 has an important role in many cases of drug resistance and that the therapeutic agents targeting these PRDXs are frequently studied for the treatment of cancer [34]. While PRDX3, PRDX4, and PRDX6 play a tumor-promoting role in the progression of many cancers [35-37], PRDX5, similar to PRDX1, has an antitumor effect in breast cancer development $[38,39]$.

Thioredoxins. Thioredoxins (Trxs) protect cells from oxidative stress by means of their 2-cysteine active site that reacts with ROS and is able to reduce oxidized proteins. They also serve as hydrogen donors to the thioredoxin-dependent peroxide reductases. Trxl, expressed in the cytoplasm and the nucleus, and Trx2, expressed in the mitochondria, are indispensable for cell survival [40]. Nuclear Trxl has been shown to be overexpressed in in situ breasttumors [41], in melanoma, lung, colon, cervix, gastric, liver, and pancreatic carcinomas [42-45].

Glutathione. Glutathione (GSH) is the major cellular thiol protein, consisting of three amino acids glutamine, cysteine, and glycine, and it participates in antioxidant defense, in the detoxification of xenobiotics, and in many metabolic processes such as the synthesis of proteins and nucleic acids [46]. It is synthesized from L-glutamate, L-cysteine, and glycine in two consecutive steps, catalyzed by glutamate-cysteine ligase (GCL) and glutathione synthase (GS) [47]. GCL is considered the rate-limiting enzyme of GSH synthesis. While GSH loss, or a decrease in glutathione/glutathione disulphide ratio (GSH/GSSG), leads to an increased susceptibility to oxidative stress and to carcinogenesis, elevated GSH levels increase the antioxidant capacity of many cancer cells enhancing their resistance to oxidative stress [48]. Remarkably, the inhibition of GSH and Trx dependent pathways induces a synergistic cancer cell death, demonstrating the importance of these two antioxidants in favoring tumor progression [49]. Glutathione peroxidases (GPx) are another group of enzymes capable of reducing hydroperoxides, including lipid hydroperoxides, using GSH as a substrate and generating GSSG which is, once again, reduced by the specific enzyme glutathione reductase (GR). A proline-leucine substitution at codon 198 of human
GPx has been associated with the increased risk of breast [50, 51], lung [52], and bladder cancer [53].

Heme Oxygenase. Heme oxygenase (HO)-1 is the first ratelimiting enzyme in the degradation of heme into biliverdin/ bilirubin, carbon monoxide (CO), and free iron [54]. Normally expressed at low levels in most of the mammalian tissues, HO-1 expression is efficiently upregulated by the availability of its substrate heme and by different stress stimuli such as heavy metals, UV irradiation, ROS, nitric oxide, and inflammatory cytokines [55]. By increasing the availability of bilirubin, ferritin, and $\mathrm{CO}$, with antioxidant and antiapoptotic properties, HO-1 is recognized as a key player in the maintenance of cellular homeostasis and in the adaptive response to cellular stressors [56]. For this reason, HO-1 activity is crucial in the protection of healthy cells, maintaining cell viability and counteracting ROS-mediated carcinogenesis as well [57]. However, the involvement of HO-1 in cancer cell biology has been proven [58] and the upregulation of $\mathrm{HO}-1$ has been widely related to cancer cell metastatic and proangiogenetic potential and poor prognosis [59-61]. Nevertheless, the role of HO- 1 seems to be strongly dependent on the types of tumor considered. For instance, in breast cancer cells, HO-1 activity reduces cell proliferation and favors the efficacy of certain drugs $[62,63]$. Thus, it is important to note that the metabolic status of cancer cells may influence HO-1 expression that is dependent on different signaling pathways and transcription factors, suggesting a possible, but not completely understood, regulation of HO-1 [64]. In addition, it has been recently demonstrated that the response of myeloma cells to bortezomib could be due to the noncanonical functions of HO1 which translocates to the nucleus where it plays a role in genetic instability, favoring cancer progression independently of its enzymatic activity [65]. Within this context, the nuclear localization of HO-1 has also been demonstrated to be involved in the gain of resistance to other chemotherapeutic agents such as imatinib in chronic myeloid leukemia [66]. As a whole, these findings open up a new scenario of the role of HO-1 in cancer cell biology.

\section{Redox-Signaling Pathways Involved in Tumorigenesis and in Tumor Progression}

In many tumors dysregulation of proliferation, apoptosis, and autophagy depends on the constitutive activation of redoxsensitive targets such as protein kinase $\mathrm{C}$ (PKC), protein kinase B (Akt), mitogen-activated protein kinases (MAPK), and ataxia telangiectasia mutated (ATM) kinase [135].

2.1. Protein Kinase C. Among redox-modulated signaling molecules playing a role in cancer, PKC may be activated by oxidative modifications of its enzymatic structure [136-138]. In this regard, in vivo and in vitro studies have demonstrated that high doses of prooxidant compounds cause PKC inactivation and proteolytic degradation while low doses induce the stimulation of the kinase activity [139-142].

For most PKC isoenzymes there is conflicting evidence as to whether they act as oncogenes or as tumor suppressors [143]. For example, the overexpression of PKC $\alpha$ has been 
demonstrated in prostate, endometrial, and high-grade urinary bladder carcinoma [144] while downregulation of PKC $\alpha$ has been described in basal cell carcinoma and colon cancers $[145,146]$. Also PKC $\beta$ overexpression is an early event in colon cancer development [147] and the transgenic overexpression of PKC $\beta$ II induces hyperproliferation and invasiveness of intestine epithelial cells [148]. It has been reported that $\mathrm{PKC} \beta$ isoenzyme is responsible for the activation/phosphorylation of p66/shc, which can bind to cytochrome $c$ and stimulate the generation of ROS [149]. Recent findings have demonstrated that PKC $\alpha$ plays a critical role in hepatocarcinoma development by inducing DUOX (a member family of NOX) expression and ROS production [150]. Moreover, also PKC $\delta$ has been shown to be implicated in NOX activation that via alterations of redox state influence retinoic acidinduced differentiation of neuroblastoma cells [151]. Likewise, PKC $\delta$ can act as either a positive or a negative regulator of tumor progression $[152,153]$. Specifically, PKC $\delta$ may be overexpressed in colon cancers and downregulated in malignant gliomas, bladder carcinomas, and endometrial tumors [154]. Moreover, while the upregulation of $\mathrm{PKC} \delta$, in breast cancer patients, has been linked with the acquisition of resistance to tamoxifen [155] the overexpression of PKC $\delta$ in neuroblastoma cells induces apoptosis by sensitizing cells to etoposide [156].

2.2. PI3K/AKT. PI3K/AKT signaling contributes to tumorigenesis and to the expression of different cancer hallmarks. It facilitates the invasion and metastasis of cancer cells by promoting matrix metalloproteinase-9 (MMP-9) secretion [157] and by inducing the epithelial mesenchymal transition (EMT) [158] while it also increases telomerase activity and replication by activating telomerase reverse transcriptase (TERT) [159].

Furthermore, the PI3K/AKT signaling pathway has been found to activate NOX with production of ROS that on one hand may increase the genomic instability of cancer cells [160] and on the other hand may render cancer cells more sensitive to chemotherapy [161]. In addition, the upregulation of PTEN (phosphatase and tensin homolog deleted on chromosome 10), a tumor suppressor gene frequently deleted or mutated in many human cancers, has been demonstrated to reduce ROS generation by regulating the PI3K/AKT pathway [162]. ROS-dependent PTEN inactivation shifts the kinasephosphatase balance in favor of tumorigenic tyrosine kinase receptor signaling through Akt, which inhibits apoptosis by phosphorylating and inactivating several targets, including Bad, forkhead transcription factors, and c-Raf and caspase9 [163].

2.3. Apoptosis Signal-Regulating Kinase 1 (ASK1) and p38 $M A P K$. Apoptosis signal-regulating kinase 1 (ASK1) has been shown to act as a redox sensor by mediating the sustained activation of JNK and p38MAPK [164] resulting in apoptosis upon oxidative stress conditions [165]. In its inactive state, ASK1 is coupled to the reduced form of Trx 1 that induces its ubiquitination and degradation [166].

As above reported, p38 MAPK is able to inhibit tumor initiation by inducing apoptosis, by regulating cell cycle progression, and/or by inducing premature senescence of primary cells [167] This protein kinase contains four active cysteine residues that can be potentially oxidized. Although the activation of $\mathrm{p} 38 \alpha$ is normally associated with antiproliferative functions $[168,169]$, several studies indicate that p38 $\alpha$ can positively modulate cancer progression [170] as observed in malignant hematopoietic cells [171] and in other tumor cell lines [172]. Consistent with the prooncogenic role of p38MAPK, the inhibition of p38MAPK activity has been found to impair the proliferation and anchorage-independent growth of neuroblastoma cells [173].

2.4. Ataxia Telangiectasia Mutated (ATM) Kinase. A critical enzyme in maintaining genome stability is ATM, which can regulate DNA damage repair [174]. In fact, ATM upregulates the glucose-6-phosphate dehydrogenase to promote NADPH production and thus reduces ROS levels [175]. In cancer stem cells (CSCs), the ATM signaling pathway is highly active. In CD44+/CD24- stem-like cells, compared with other cell populations from breast cancer, the expression of ATM was significantly increased [176] and the employment of an ATM inhibitor reversed their resistance to radiotherapy, suggesting the importance of ATM signaling in CSC formation [176].

\section{Role of Transcription Factors as ROS Modulators in Carcinogenesis and Cancer Progression}

Many transcription factors are key players in regulating several pathways involved in carcinogenesis and cancer progression. Through their binding to the gene promoter regions, they can transactivate or repress the expression of antioxidant genes leading to the alteration in redox state and changes in proliferation, growth suppression, differentiation, and senescence.

3.1. $p 53$. $p 53$ functions as a transcription factor able to activate or repress a large number of target genes that are involved in cell cycle control, DNA repair, apoptosis, and cellular stress responses [177]. It is kept at low levels by several E3 ubiquitin ligases, such as Mdm2, responsible for its degradation [178], and it is stabilized by posttranslational modifications such as phosphorylation, acetylation, and methylation $[179,180]$.

p53 has a controversial role in ROS regulation as it can promote both pro- and antioxidant responses [174].

Stress-induced p53 activation leads to the upregulation of several genes encoding ROS-generating enzymes, such as NQO1 (quinone oxidoreductase) [181] and proline oxidase (POX) [182], and redox-active proteins, including Bax and Puma. In particular, p53-induced ROS overproduction may be due to the overexpression of Puma, a critical mediator of mitochondrial membrane impairment [183], to the transcriptional activation of p67phox, a component of NADPH oxidase responsible for $\mathrm{O}_{2}{ }^{\circ-}$ production [184] and to the action of p66Shc which oxidizes cytochrome $\mathrm{c}$ and affects mitochondrial permeability [149].

Moreover, the prooxidant activity of p53 has been found to be modulated by several genes named PIG1-13 (p53inducible genes 1-13) which are able to encode redox-active 
proteins [181]. In particular, PIG1, a member of the galectin family, is involved in superoxide production; PIG3, homolog of NADPH-quinone oxidoreductase, is a potent ROS generator and PIG8, a human homolog of mouse E-24 gene, is a quinone able to regulate ROS [181].

In contrast, $\mathrm{p} 53$ is also able to transactivate different genes controlling antioxidant response in order to maintain ROS production at nontoxic levels [185]. In fact, p53 has been found to activate MnSOD expression via the direct recognition of the MnSOD human gene promoter [186] and to induce the expression of heme-oxygenase-1 (HO-1) by directly binding to the HO-1 promoter, favoring cell survival [187].

Another important antioxidant target of p53 is Tp53induced glycolysis and apoptosis regulator (TIGAR) [188]. TIGAR encodes a protein that is similar to the glycolytic enzyme fructose-2,6-bisphosphatase, which degrades fructose-2,6-bisphosphate [189]. A decrease in fructose-2,6bisphosphate levels inhibits the activity of the rate-limiting enzyme phosphofructokinase I (PFK1), thereby blocking glycolysis and promoting the shuttling of metabolites to the pentose phosphate pathway (PPP). By upregulating TIGAR, p53 amplifies PPP-mediated NADPH production that is required by glutathione reductase in order to convert GSSG to GSH. A third important antioxidant target of p53 is glutaminase 2 (GLS2) that converts glutamine to glutamate which is subsequently converted to GSH via GCLC and GCLM [190].

3.2. $N r f 2$. $N r f 2$ is a transcription factor that controls not only the expression of antioxidants as well as phase I and phase II drug metabolizing systems, but also multidrug-resistanceassociated protein transporters [58]. In a resting state, Nrf2 is sequestered in the cytoplasm through the binding with Keap1, responsible for Nrf2 ubiquitination and proteasomal degradation via Cul3. Oxidative/electrophilic stress causes a conformational change in Keapl-Cul3 by acting on specific residues in Keapl, leading to Nrf2 dissociation. Thus, Nrf2 translocates to the nucleus where it dimerizes with a small Maf protein and binds to the antioxidant response element (ARE) sequence within regulatory regions of a wide variety of target genes [191, 192]. In fact, Nrf2 is essential for the expression of stress-responsive or cytoprotective enzymes such as NQO1, SODs, HO-1, catalase, and Trx. In addition, Nrf2 activation regulates GSH levels and metabolism by inducing the expression of GCL, GS, GSH S-transferases (GSTs), GR, and GPx $[193,194]$.

Several mechanisms have been shown to be involved in the constitutive activation of Nrf2 in cancer cells, mainly gain-of-function mutations in Nrf2 and loss-of-function mutations in Keap1 [195-198]. Shibata et al. [199] have reported that Keap1 and Nrf2 mutations, in lung cancer, are responsible for the upregulation of ARE-modulated genes, which favor cancer promotion and/or progression [58]. Recently, these alterations of Keap1/Nrf2 pathway have been considered among the potential novel targets for the treatment of lung adenocarcinoma [200].

Among Nrf2 target genes glucose-6-phosphate dehydrogenase, phosphogluconate dehydrogenase, transketolase, and transaldolase I are responsible for NADPH and purine regeneration and then accelerate cancer cell proliferation [201].
Moreover, Nrf2 is directly involved in the basal expression of the p53 inhibitor Mdm2, through the binding to the ARE sequence located in the first intron of this gene, and inhibits cell death [202]. Cancer cells with high levels of Nrf2 have been shown to be less sensitive to etoposide, cisplatin, and doxorubicin [203] and our studies demonstrated that activation of Nrf2 and of its target genes plays a key role in the resistance of neuroblastoma cells to GSH depletion or proteasome inhibition $[85,204]$.

3.3. NF- $\kappa B$. The transcriptionfactor NF- $\kappa B$ plays a critical role in cell survival, proliferation, immunity, and inflammation [205]. In stimulated cells, I- $\kappa \mathrm{B}$, an endogenous inhibitor able to retain NF- $\kappa \mathrm{B}$ in the cytoplasm, is phosphorylated by $\mathrm{I}-\kappa \mathrm{B}$ kinase (IKK) which leads to $\mathrm{I}-\kappa \mathrm{B}$ ubiquitination and proteasomal degradation and induces NF- $\kappa$ B translocation to the nucleus where it can modulate the transcription of its target genes [206]. Morgan and Liu showed that ROS may regulate NF- $\kappa \mathrm{B}$ activation to express antioxidant genes coding MnSOD, Cu,Zn-SOD, catalase, Trx, GST-pi, HO-1, and GPx [207]. NF- $\kappa$ B is also involved in the regulation of some enzymes catalyzing ROS production such as NOX2, xanthine oxidoreductase, NOS, and COX-2 [208].

NF- $\kappa$ B activation leads to the development and/or progression of cancer by upregulating several genes involved in cell transformation, proliferation, and angiogenesis [209]. In this regard, it has been found that NF- $\kappa \mathrm{B}$ activation and ROS production promote the progression of hepatocellular carcinoma [210] and the initiation of colorectal cancer [211]. Moreover, as observed in high-risk myelodysplastic syndrome and in AML patients, NF- $\kappa$ B activation, due to the constitutive activation of ATM [212], is critical for the survival of human leukemia cells [213] by increasing MnSOD activity, reducing ROS levels and inhibiting oxidative cell death.

3.4. HIF-1. Hypoxia-inducible factor (HIF-1) is a heterodimeric transcription factor composed of an $\alpha$-subunit (HIF-1 $\alpha$ ) and a $\beta$-subunit (HIF-1 $\beta$ ) [214]. The expression of HIF- $1 \alpha$ is mainly regulated at the posttranslational level in an oxygen-dependent manner and is largely responsible for the regulation of HIF-1 activity [215].

It has been demonstrated that HIF- $1 \alpha$ interacts with the HIF- $1 \beta$ and acts as a transcription factor able to induce the expression of genes involved in metabolic adaptation, such as hexokinase II (HK II) and pyruvate dehydrogenase kinase 1 (PDK1) [216], and the expression of genes involved in improving oxygen availability $[217,218]$ and shifting the glucose metabolism from mitochondrial oxidative phosphorylation to anaerobic glycolysis [219].

In addition, it has been demonstrated that ROS, via the modulation of PI3K/AKT and ERK pathways, are able to activate HIF-1 in hypoxic tumors [220]. In fact, HIF-1 overexpression correlates with poor outcomes in patients with head, neck, nasopharyngeal, colorectal, pancreatic, breast, cervical, bone, endometrial, ovarian, bladder, glial, and gastric cancers [9] and it is associated with refractiveness to conventional therapies [221]. 
TABLE 1: ROS modulating drugs undergoing clinical trials in oncology.

\begin{tabular}{|c|c|c|c|c|}
\hline Drug & Mechanism of action & Cancer type & Outcome & Ref. \\
\hline $\begin{array}{l}\text { L-Buthionine- } \\
\text { sulfoximine }\end{array}$ & Inhibits GSH synthesis; activates $\mathrm{PKC} \delta$ & $\begin{array}{l}\text { Neuroblastoma } \\
\text { Melanoma }\end{array}$ & Efficacious in vitro & {$[67-73]$} \\
\hline Menadione & $\begin{array}{l}\text { Depletes GSH; activates ERK1/2 and } \\
\text { p38MAPK }\end{array}$ & Gastrointestinal and lung cancer & Under clinical trial & [74-77] \\
\hline Imexon & $\begin{array}{l}\text { Depletes intracellular thiols; increases } \\
\text { AP-1 and Nrf2-DNA binding activity }\end{array}$ & $\begin{array}{l}\text { Advanced breast cancer; NSCLC; } \\
\text { prostate and pancreatic tumors }\end{array}$ & Efficacious & {$[78-82]$} \\
\hline Disulfiram & $\begin{array}{l}\text { Oxidizes GSH and inhibits } \\
\text { proteasome; activates JNK; inhibits } \\
\text { Nrf2 and NF- } \kappa \text { B }\end{array}$ & $\begin{array}{l}\text { Metastatic melanoma; liver } \\
\text { cancer }\end{array}$ & Under clinical trial & {$[68,83,84]$} \\
\hline Bortezomib & $\begin{array}{l}\text { Inhibits proteasome activity; activates } \\
\text { NF- } \kappa B \text {; activates Nrf } 2 \text { and upregulates } \\
\mathrm{HO}-1\end{array}$ & $\begin{array}{l}\text { Myeloma, leukemia, AML, } \\
\text { myelodysplastic syndrome, } \\
\text { neuroblastoma, prostate cancer }\end{array}$ & Under clinical trial & [85-90] \\
\hline NOV-002 & $\begin{array}{l}\text { Oxidizes GSH and induces } \\
\text { S-glutathionylation }\end{array}$ & $\begin{array}{l}\text { NSCLC; breast and ovarian } \\
\text { cancer }\end{array}$ & Efficacious & [91-93] \\
\hline Ezatiostat & $\begin{array}{l}\text { Inhibits GST-P1 and activates } \\
\text { JNK/ERK }\end{array}$ & Myelodysplastic syndrome & Under clinical trial & {$[94]$} \\
\hline PX-12 & Inactivates Trx-1 & Advanced solid tumors & Efficacious & [95-97] \\
\hline Dimesna & Targets Trx and Grx & Ovarian carcinoma, NSCLC & Efficacious & {$[95,98,99]$} \\
\hline $\begin{array}{l}\text { Motexafin } \\
\text { gadolinium }\end{array}$ & Inhibits Trx & $\begin{array}{l}\text { Pancreatic, biliary and } \\
\text { haematological cancer, renal } \\
\text { carcinoma }\end{array}$ & Under clinical trial & {$[97,100-102]$} \\
\hline $\begin{array}{l}\text { Arsenic } \\
\text { trioxide }\end{array}$ & Oxidizes GSH and thiol enzymes & APL, melanoma & Efficacious & {$[68]$} \\
\hline
\end{tabular}

\section{ROS-Modulating Agents Undergoing Clinical Trials in Oncology}

Several anticancer drugs are able to produce high levels of ROS leading to DNA damage and apoptosis $[222,223]$ that can be further stimulated by depleting cancer cell of GSH. The following compounds alter the intracellular redox state and induce cell death; for this reason some of them have been employed to improve the cytotoxic effects of conventional drugs (Table 1).

L-Buthionine-S,R-sulfoximine (BSO) induces oxidative stress by inhibiting GSH biosynthesis [67] and it synergizes with cytotoxic chemotherapeutic agents, including arsenic trioxide, cisplatin, doxorubicin, and melphalan [68]. Our studies have demonstrated that BSO-induced ROS overproduction and apoptosis of neuroblastoma cells is mediated by PKC $\delta$ activation [69-72] which is crucial for the sensitization of cancer cells to BSO and to etoposide [156]. In this context, BSO plus melphalan is currently undergoing clinical evaluation in children with neuroblastoma and in patients with persistent or recurrent stage III malignant melanoma [73].

Menadione (also known as vitamin K3) is a synthetic derivative of vitamins $\mathrm{K} 1$ and $\mathrm{K} 2$. The oxidative stress generated by menadione is dose-dependent and is due to GSH depletion capable of inducing cell death [74]. Moreover, a recent study reported that menadione analogues at submicromolar concentrations activate apoptosis of myeloid leukemia cells via the activation of ERK $1 / 2$ and p38MAPK [75]. In vitro investigations have led to the employment of menadione in different human trials in patients with gastrointestinal and lung cancer $[76,77]$.
Imexon is a prooxidant small molecule that depletes intracellular thiols generating oxidative stress and, subsequently, induces apoptosis [78]. Preclinical studies have demonstrated that imexon treatment increases nuclear Nrf2 levels and AP-1DNA binding activity in myeloma cells and breast cancer cells [79]. These findings suggest that imexon leads to an adaptive response to oxidative stress involving upregulation of several antioxidant genes such as Nrf2 [79] and CuZnSOD [224]. The increased antioxidant gene expression and the enhancement of GSH levels in myeloma cell lines have been associated with the phenomenon of resistance to imexon [225].

Successful phase I trials have been completed in combination with cytotoxic chemotherapy in advanced breast, nonsmall cell lung cancer (NSCLC), prostate [80], and pancreatic [81] tumors. In addition, a phase II study has been carried out in patients with relapsed/refractory B-cell non-Hodgkin lymphoma [82].

Disulfiram is an acetaldehyde dehydrogenase inhibitor that induces apoptosis via GSH oxidation and proteasome inhibition $[68,83]$. Preclinical studies have demonstrated that disulfiram-induced apoptosis of human melanoma cells [226] and of lymphoid malignant cells is mediated by JNK activation and Nrf2 and NF- $\kappa$ B inhibition [84]. A phase I/II trial with disulfiram has recently been completed in patients with metastatic melanoma and other early-phase studies are ongoing in NSCLC and treatment-refractory liver tumors [68].

Bortezomib is a proteasome inhibitor that blocks inducible I- $\kappa \mathrm{B}$ degradation and consequently activates NF- $\kappa \mathrm{B}[86$, 87]. It induces cell cycle arrest and apoptosis by preventing the degradation of p21/waf1, p53, and Bax [227]. Bortezomib has been extensively studied either alone or in combination 
with other agents for the treatment of multiple myeloma [86] and of chronic lymphocytic leukemia (CLL) [88]. In addition, bortezomib has been demonstrated to exert cytotoxicity by increasing ROS production [228] and, in this context, our recent studies have shown that bortezomib treatment of human neuroblastoma cells is less effective as a consequence of Nrf2-mediated HO-1 upregulation [85]. Moreover, it has been reported that bortezomib induces HO-1 activity in multiple myeloma via the endoplasmic reticulum stress pathway and that HO-1 nuclear translocation confers resistance to chemotherapy and induces genetic instability in cancer cells [65].

NOV-002 is a product containing oxidized glutathione that alters the GSH/GSSG ratio and induces S-glutathionylation [91]. NOV-002-induced S-glutathionylation has been shown to have inhibitory effects on proliferation, survival and invasion of myeloid cell lines and significantly increases the efficacy of cyclophosphamide chemotherapy in a murine model of colon cancer [229]. NOV-002 has been most extensively studied with a phase III trial (NCT00347412) completed in the treatment of advanced NSCLC [92] and data is available from phase II trials in breast and ovarian cancers [230]. In a randomized phase II trial, NOV-002 in combination with standard chemotherapy has shown promising effects in patients with stage IIIb/IV of NSCLC [231]. Positive results were also obtained from a phase II trial in patients with neo adjuvant breast cancer therapy [93].

Ezatiostat hydrochloride (TLK199) is a GSH analogue that inhibits GST P1-1 leading to JNK/ERK activation and inducing apoptosis of malignant cells [94]. Treatment of leukemia cell lines with ezatiostat has been demonstrated to induce myeloblast differentiation without affecting myelopoiesis [94]. Ezatiostat has been evaluated in multiple phase I and phase II clinical trials in myelodysplastic syndrome (MDS) characterized by ineffective hematopoiesis presenting with anemia and, in some cases, neutropenia and thrombocytopenia [94].

PX-12 (1-methylpropyl 2-imidazolyl disulfide) irreversibly inactivates Trx-1 which is overexpressed in many human cancers and it is associated with aggressive tumor growth and decreased patient survival [95]. Furthermore, the antitumor activity of PX-12 is also due to a reduction of VEGF in cancer patient plasma [95] and it can be synergistically enhanced after combination of PX-12 with 5-FU in HCC cells [96]. PX-12 has shown promising pharmacokinetics and pharmacodynamics in phase Ib trials in patients with advanced solid tumors refractory to chemotherapy [97].

Dimesna (BNP7787, disodium 2,2-dithio-bis-ethane sulfonate) is a novel chemoprotective disulfide compound that targets Trx and Grx which are overexpressed in many tumors $[98,99]$. Dimesna has been employed in the treatment of various solid tumors, including ovarian carcinoma and NSCLC. In addition, it is currently undergoing phase III clinical trials (NCT00966914), in combination with first-line taxane and platinum chemotherapy, in patients with diagnosed or relapsed advanced (stage IIIB/IV) NSCLC adenocarcinoma.

Motexafin gadolinium (MGd) is a Trx inhibitor that reversibly accepts electrons from NADPH, NADH, GSH, and ascorbate, with subsequent electron transfer to molecular oxygen [232]. Preclinical studies have shown that MGd alone has a proapoptotic effect in multiple myeloma, non-Hodgkin lymphoma, and chronic lymphocytic leukemia [233]. MGd has been tested in a phase I trial in patients with locally advanced pancreatic or biliary cancers [97], and in a phase II trial in renal cell carcinoma [100] and in haematological malignancies [101].

Arsenic trioxide $\left(\mathrm{As}_{2} \mathrm{O}_{3}\right)$ is an inorganic compound that has antiproliferative and apoptogenic effects on cancer cells by inducing oxidation of cysteine residues in GSH and thiol enzymes [68]. It has been approved by the European Medicines Agency and US Food and Drug Administration, for induction and consolidation of chemotherapy in adults with relapsed/refractory acute promyelocytic leukemia (APL). Moreover, $\mathrm{As}_{2} \mathrm{O}_{3}$, in combination with disulfiram, is being evaluated as a second-line therapy in phase I trials (NCT00571116) in patients with metastatic melanoma.

\section{Conclusions}

The modulation of oxidative stress is considered an important factor in the development of cancer and in the response of tumor cells to therapy [189]. As shown in this review, high ROS levels in cancer cells are a consequence of alterations in cellular metabolism and their overproduction is counteracted by elevated defense mechanisms (Figure 2).

Among antioxidants, GSH is essential for maintaining a correct redox balance, has a crucial role in the protection of cancer cells from oxidative stress, and ensures cell survival in both hypoxia and nutrient deprivation that are present in solid malignant tumors [48]. For this reason, combinations of GSH antagonists or other antioxidant inhibitors with radio or chemotherapy may be useful for killing cancer cells. This "epigenetic-genetic" therapeutic approach is in sharp contrast to the conventional strategy of targeting oncogenes and oncosuppressors, an approach that has turned out to be uneffective also for the frequent gene mutations.

As reported in this review, many of these genes are redox-sensitive transcription factors that are involved in proliferation, angiogenesis, and metastasis and are able to induce a common set of cell stress adaptive responses, thus providing a survival advantage.

Therefore, the redox-signaling pathways underlying these adaptations may represent the most critical weak point in many cancers and the signaling molecules that mediate these changes could be the next important targets for future anticancer drug discovery research.

Recently, as summarized in Table 2, many clinical trials with modulators of kinases or transcription factors associated with conventional therapy are ongoing. Although the results of some of these combined strategies seem to be promising, further studies are needed in order to identify specific markers for a more personalized therapy and to minimize the side toxic effects. 
TABLE 2: Modulators of redox signaling pathways employed in combination with anticancer agents and their effects.

\begin{tabular}{|c|c|c|c|c|}
\hline Drug & Mechanism of action & Cancer type & Outcome & Ref. \\
\hline Trametinib & MEK inhibitor & Melanoma & Efficacious & {$[103]$} \\
\hline Selumetinib & MEK inhibitor & Thyroid, ovarian cancer & Efficacious & [104-106] \\
\hline Tamoxifen & PKC inhibitor & Gliomas, breast cancer & Efficacious & [107-111] \\
\hline Perifosine & Akt, MAPK and JNK inhibitor & Haematologic tumors, myeloma & Efficacious & {$[112-116]$} \\
\hline Sulfasalazine & $\mathrm{NF}-\kappa \mathrm{B}$ inhibitor & Colorectal cancer & Efficacious & {$[117,118]$} \\
\hline Nelvinavir & Decreases HIF-1 $\alpha$ & $\begin{array}{l}\text { Adenoid cystic carcinoma, } \\
\text { pancreatic cancer, NSCLC }\end{array}$ & Efficacious & [119-122] \\
\hline Topotecan & $\begin{array}{l}\text { HIF-1 and Topoisomerase I } \\
\text { inhibitor }\end{array}$ & Endometrial and cervical cancer & Efficacious & {$[123,124]$} \\
\hline Aprinocarsen & $\begin{array}{l}\text { Antisense oligonucleotide against } \\
\text { PKC- } \alpha\end{array}$ & Lymphoma, breast cancer & Contrasting results & {$[125-127]$} \\
\hline Midostaurin & $\begin{array}{l}\text { Multitarget inhibitor of PKCs, } \\
\text { VEGFR2, PDGFR }\end{array}$ & AML, melanoma & Contrasting results & {$[128,129]$} \\
\hline MK-2206 & Akt and PI3K inhibitor & $\begin{array}{l}\text { Gastric, pancreatic and breast } \\
\text { cancer }\end{array}$ & Under clinical trial & {$[130]$} \\
\hline Serdemetan & $\mathrm{mdm} 2$ inhibitor & Refractory solid tumors & Under clinical trial & {$[131]$} \\
\hline 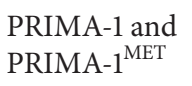 & $\begin{array}{l}\text { Reverse the oncogenic properties of } \\
\text { mutant p53 }\end{array}$ & Ovarian cancer & Under clinical trial & {$[132,133]$} \\
\hline AMG 232 & mdm2-p53 interactions inhibitor & $\begin{array}{l}\text { Melanoma, myeloma, myeloid } \\
\text { leukemia }\end{array}$ & Under clinical trial & {$[134]$} \\
\hline
\end{tabular}

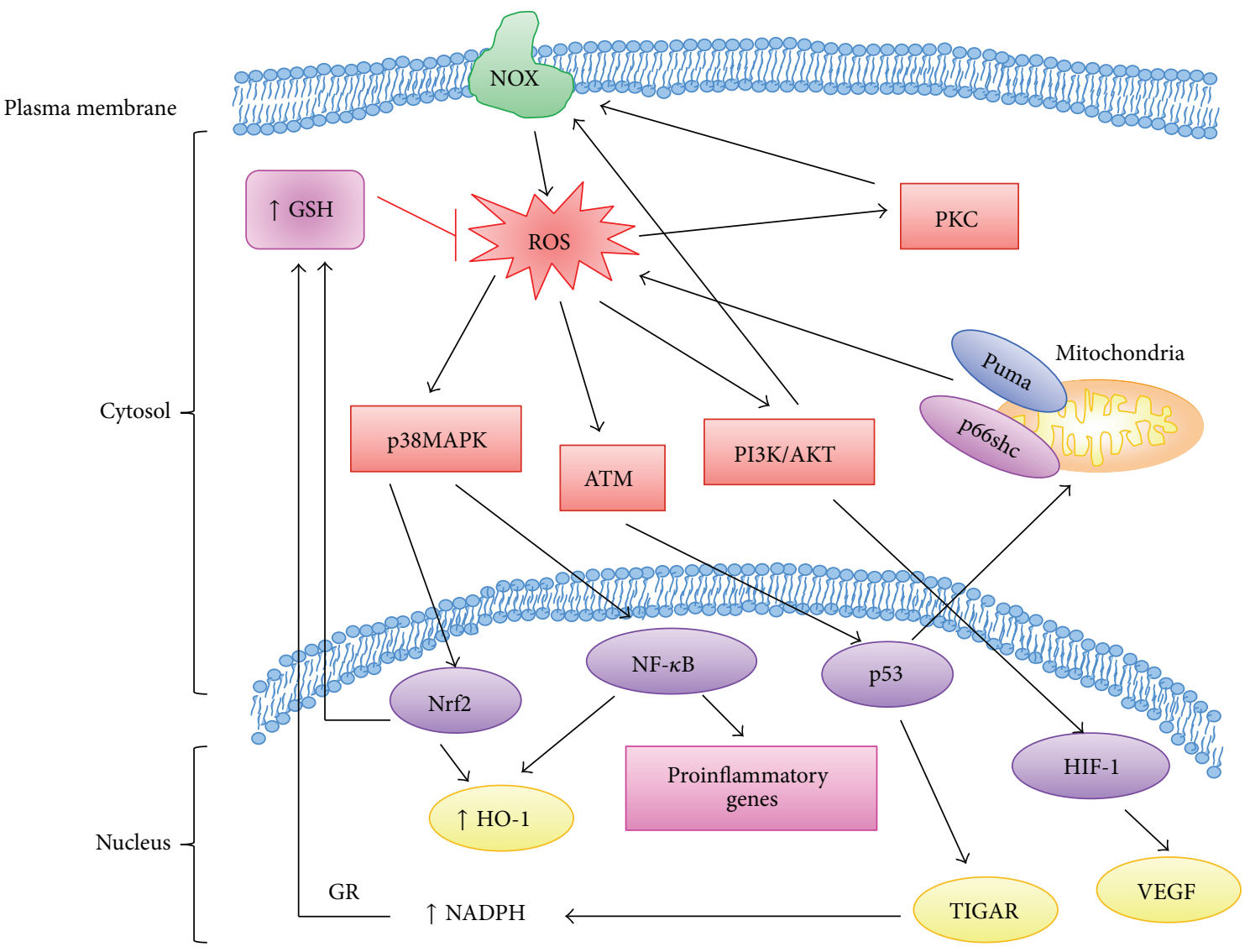

FIGURE 2: Redox-signaling pathways that are involved in cancer growth and progression. Cancer cells escape cell death and damage induced by high ROS levels by increasing their antioxidant defenses such as GSH that contribute to lower the amount of ROS. ROS are produced by NOX in the plasma membrane and by mitochondria, and at low levels they act as second messengers by activating many protein kinases (PI3/Akt, p38 MAPK, and ATM) and transcription factors (Nrf2, NF- $\kappa$ B, p53, and HIF-1) able to contribute to cancer cell survival by stimulating cell proliferation, inflammation, and angiogenesis. GR, glutathione reductase. 


\section{Competing Interests}

The authors declare that they have no competing interests.

\section{Acknowledgments}

This work was supported by grants from MIURPRIN20125S38FA (M. Nitti) and Genoa University.

\section{References}

[1] H. Wiseman and B. Halliwell, "Damage to DNA by reactive oxygen and nitrogen species: role in inflammatory disease and progression to cancer," Biochemical Journal, vol. 313, no. 1, pp. 17-29, 1996.

[2] T. Finkel, "Signal transduction by mitochondrial oxidants," The Journal of Biological Chemistry, vol. 287, no. 7, pp. 4434-4440, 2012.

[3] Y. M. W. Janssen-Heininger, B. T. Mossman, N. H. Heintz et al., "Redox-based regulation of signal transduction: principles, pitfalls, and promises," Free Radical Biology and Medicine, vol. 45, no. 1, pp. 1-17, 2008.

[4] H. J. Forman, M. Torres, and J. Fukuto, "Redox signaling," Molecular and Cellular Biochemistry, vol. 234-235, pp. 49-62, 2002.

[5] L.-Z. Liu, X.-W. Hu, C. Xia et al., "Reactive oxygen species regulate epidermal growth factor-induced vascular endothelial growth factor and hypoxia-inducible factor- $1 \alpha$ expression through activation of AKT and P70S6K1 in human ovarian cancer cells," Free Radical Biology and Medicine, vol. 41, no. 10, pp. 1521-1533, 2006.

[6] S. Zhou, S. Kachhap, W. Sun et al., "Frequency and phenotypic implications of mitochondrial DNA mutations in human squamous cell cancers of the head and neck," Proceedings of the National Academy of Sciences of the United States of America, vol. 104, no. 18, pp. 7540-7545, 2007.

[7] M. Benhar, D. Engelberg, and A. Levitzki, "ROS, stressactivated kinases and stress signaling in cancer," EMBO Reports, vol. 3, no. 5, pp. 420-425, 2002.

[8] C. Pantano, N. L. Reynaert, A. van der Vliet, and Y. M. W. Janssen-Heininger, "Redox-sensitive kinases of the nuclear factor- $\kappa \mathrm{B}$ signaling pathway," Antioxidants and Redox Signaling, vol. 8, no. 9-10, pp. 1791-1806, 2006.

[9] E. B. Rankin and A. J. Giaccia, "The role of hypoxia-inducible factors in tumorigenesis," Cell Death and Differentiation, vol. 15, no. 4, pp. 678-685, 2008.

[10] J. M. McCord and I. Fridovich, "Superoxide dismutase. An enzymic function for erythrocuprein (hemocuprein)," Journal of Biological Chemistry, vol. 244, no. 22, pp. 6049-6055, 1969.

[11] Y. Li, T.-T. Huang, E. J. Carlson et al., "Dilated cardiomyopathy and neonatal lethality in mutant mice lacking manganese superoxide dismutase," Nature Genetics, vol. 11, no. 4, pp. 376381, 1995.

[12] C. G. Pham, C. Bubici, F. Zazzeroni et al., "Ferritin heavy chain upregulation by NF- $\kappa \mathrm{B}$ inhibits TNF $\alpha$-induced apoptosis by suppressing reactive oxygen species," Cell, vol. 119, no. 4, pp. 529-542, 2004.

[13] D. Kang, K.-M. Lee, K. P. Sue et al., "Functional variant of manganese superoxide dismutase (SOD2 V16A) polymorphism is associated with prostate cancer risk in the prostate, lung, colorectal, and ovarian cancer study," Cancer Epidemiology Biomarkers and Prevention, vol. 16, no. 8, pp. 1581-1586, 2007.

[14] G. Liu, W. Zhou, L. I. Wang et al., "MPO and SOD2 polymorphisms, gender, and the risk of non-small cell lung carcinoma," Cancer Letters, vol. 214, no. 1, pp. 69-79, 2004.

[15] S. H. Olson, M. D. A. Carlson, H. Ostrer et al., "Genetic variants in SOD2, MPO, and NQO1, and risk of ovarian cancer," Gynecologic Oncology, vol. 93, no. 3, pp. 615-620, 2004.

[16] S. S. Wang, S. Davis, J. R. Cerhan et al., "Polymorphisms in oxidative stress genes and risk for non-Hodgkin lymphoma," Carcinogenesis, vol. 27, no. 9, pp. 1828-1834, 2006.

[17] G. Ray, S. Batra, N. K. Shukla et al., "Lipid peroxidation, free radical production and antioxidant status in breast cancer," Breast Cancer Research and Treatment, vol. 59, no. 2, pp. 163170, 2000.

[18] F. Tas, H. Hansel, A. Belce et al., "Oxidative stress in breast cancer," Medical Oncology, vol. 22, no. 1, pp. 11-15, 2005.

[19] J. Yang, E. W. N. Lam, H. M. Hammad, T. D. Oberley, and L. W. Oberley, "Antioxidant enzyme levels in oral squamous cell carcinoma and normal human oral epithelium," Journal of Oral Pathology and Medicine, vol. 31, no. 2, pp. 71-77, 2002.

[20] J. J. Cullen, F. A. Mitros, and L. W. Oberley, "Expression of antioxidant enzymes in diseases of the human pancreas: another link between chronic pancreatitis and pancreatic cancer," Pancreas, vol. 26, no. 1, pp. 23-27, 2003.

[21] R. Kumaraguruparan, J. Kabalimoorthy, and S. Nagini, "Correlation of tissue lipid peroxidation and antioxidants with clinical stage and menopausal status in patients with adenocarcinoma of the breast," Clinical Biochemistry, vol. 38, no. 2, pp. 154-158, 2005.

[22] I. Beno, M. Staruchova, K. Vokovova, and M. Batovsky, "Increased antioxidant enzyme activities in the colorectal adenoma and carcinoma," Neoplasma, vol. 42, no. 5, pp. 265-269, 1995.

[23] K. Kahlos, S. Anttila, T. Asikainen et al., "Manganese superoxide dismutase in healthy human pleural mesothelium and in malignant pleural mesothelioma," American Journal of Respiratory Cell and Molecular Biology, vol. 18, no. 4, pp. 570-580, 1998.

[24] A. Perkins, K. J. Nelson, D. Parsonage, L. B. Poole, and P. A. Karplus, "Peroxiredoxins: guardians against oxidative stress and modulators of peroxide signaling," Trends in Biochemical Sciences, vol. 40, no. 8, pp. 435-445, 2015.

[25] M. H. Park, M. Jo, Y. R. Kim et al., "Roles of peroxiredoxins in cancer, neurodegenerative diseases and inflammatory diseases," Pharmacology \& Therapeutics, vol. 163, pp. 1-23, 2016.

[26] R. A. Egler, E. Fernandes, K. Rothermund et al., "Regulation of reactive oxygen species, DNA damage, and c-Myc function by peroxiredoxin 1," Oncogene, vol. 24, no. 54, pp. 8038-8050, 2005.

[27] J. Cao, J. Schulte, A. Knight et al., "Prdx1 inhibits tumorigenesis via regulating PTEN/AKT activity;" The EMBO Journal, vol. 28, no. 10, pp. 1505-1517, 2009.

[28] V. L. Kinnula, S. Lehtonen, R. Sormunen et al., "Overexpression of peroxiredoxins I, II, III, V, and VI in malignant mesothelioma," Journal of Pathology, vol. 196, no. 3, pp. 316-323, 2002.

[29] S. T. Lehtonen, A.-M. Svensk, Y. Soini et al., "Peroxiredoxins, a novel protein family in lung cancer," International Journal of Cancer, vol. 111, no. 4, pp. 514-521, 2004.

[30] T. Yanagawa, S. Iwasa, T. Ishii et al., "Peroxiredoxin I expression in oral cancer: a potential new tumor marker," Cancer Letters, vol. 156, no. 1, pp. 27-35, 2000. 
[31] J. Shen, M. D. Person, J. Zhu, J. L. Abbruzzese, and D. $\mathrm{Li}$, "Protein expression profiles in pancreatic adenocarcinoma compared with normal pancreatic tissue and tissue affected by pancreatitis as detected by two-dimensional gel electrophoresis and mass spectrometry," Cancer Research, vol. 64, no. 24, pp. 9018-9026, 2004.

[32] W. Lu, Z. Fu, H. Wang, J. Feng, J. Wei, and J. Guo, "Peroxiredoxin 2 is upregulated in colorectal cancer and contributes to colorectal cancer cells' survival by protecting cells from oxidative stress," Molecular and Cellular Biochemistry, vol. 387, no. 1-2, pp. 261-270, 2014.

[33] M. Shiota, A. Yokomizo, E. Kashiwagi et al., "Peroxiredoxin 2 in the nucleus and cytoplasm distinctly regulates androgen receptor activity in prostate cancer cells," Free Radical Biology and Medicine, vol. 51, no. 1, pp. 78-87, 2011.

[34] Y.-G. Wang, L. Li, C.-H. Liu, S. Hong, and M.-J. Zhang, "Peroxiredoxin 3 is resistant to oxidation-induced apoptosis of Hep-3b cells," Clinical and Translational Oncology, vol. 16, no. 6, pp. 561-566, 2014.

[35] H. C. Whitaker, D. Patel, W. J. Howat et al., "Peroxiredoxin-3 is overexpressed in prostate cancer and promotes cancer cell survival by protecting cells from oxidative stress," British Journal of Cancer, vol. 109, no. 4, pp. 983-993, 2013.

[36] Q. Wei, H. Jiang, Z. Xiao et al., "Sulfiredoxin-Peroxiredoxin IV axis promotes human lung cancer progression through modulation of specific phosphokinase signaling," Proceedings of the National Academy of Sciences of the United States of America, vol. 108, no. 17, pp. 7004-7009, 2011.

[37] T. H. Kim, J. Song, S. R. Alcantara Llaguno et al., "Suppression of peroxiredoxin 4 in glioblastoma cells increases apoptosis and reduces tumor growth," PLoS ONE, vol. 7, no. 8, Article ID e42818, 2012.

[38] A. Elamin, H. Zhu, A. M. Hassan et al., "Peroxiredoxin V: a candidate breast tumor marker of population specificity," Molecular and Clinical Oncology, vol. 1, no. 3, pp. 541-549, 2013.

[39] H.-M. Yun, K.-R. Park, M. H. Park et al., "PRDX6 promotes tumor development via the JAK2/STAT3 pathway in a urethaneinduced lung tumor model," Free Radical Biology and Medicine, vol. 80, pp. 136-144, 2015.

[40] T. Tanaka, F. Hosoi, Y. Yamaguchi-Iwai et al., "Thioredoxin2 (TRX-2) is an essential gene regulating mitochondriadependent apoptosis," The EMBO Journal, vol. 21, no. 7, pp. 1695-1703, 2002.

[41] N. Turunen, P. Karihtala, A. Mäntyniemi et al., “Thioredoxin is associated with proliferation, p53 expression and negative estrogen and progesterone receptor status in breast carcinoma," Acta Pathologica, Microbiologica et Immunologica Scandinavica, vol. 112, no. 2, pp. 123-132, 2004.

[42] S. Fujii, Y. Nanbu, H. Nonogaki et al., "Coexpression of adult Tcell leukemia-derived factor, a human thioredoxin homologue, and human papillomavirus DNA in neoplastic cervical squamous epithelium," Cancer, vol. 68, no. 7, pp. 1583-1591, 1991.

[43] H. Nakamura, H. Masutani, Y. Tagaya et al., "Expression and growth-promoting effect of adult T-cell leukemia-derived factor: a human thioredoxin homologue in hepatocellular carcinoma," Cancer, vol. 69, no. 8, pp. 2091-2097, 1992.

[44] Y. Soini, K. Kahlos, U. Näpänkangas et al., "Widespread expression of thioredoxin and thioredoxin reductase in non-small cell lung carcinoma," Clinical Cancer Research, vol. 7, no. 6, pp. 17501757, 2001.
[45] D. T. Lincoln, E. M. Ali Emadi, K. F. Tonissen, and F. M. Clarke, "The thioredoxin-thioredoxin reductase system: overexpression in human cancer," Anticancer Research, vol. 23, no. 3B, pp. 2425-2433, 2003.

[46] H. Sies, "Glutathione and its role in cellular functions," Free Radical Biology and Medicine, vol. 27, no. 9-10, pp. 916-921, 1999.

[47] O. W. Griffith, "Biologic and pharmacologic regulation of mammalian glutathione synthesis," Free Radical Biology and Medicine, vol. 27, no. 9-10, pp. 922-935, 1999.

[48] N. Traverso, R. Ricciarelli, M. Nitti et al., "Role of glutathione in cancer progression and chemoresistance," Oxidative Medicine and Cellular Longevity, vol. 2013, Article ID 972913, 10 pages, 2013.

[49] I. S. Harris, A. E. Treloar, S. Inoue et al., "Glutathione and thioredoxin antioxidant pathways synergize to drive cancer initiation and progression," Cancer Cell, vol. 27, no. 2, pp. 211222, 2015.

[50] G. Ravn-Haren, A. Olsen, A. Tjønneland et al., "Associations between GPX1 Pro198Leu polymorphism, erythrocyte GPX activity, alcohol consumption and breast cancer risk in a prospective cohort study," Carcinogenesis, vol. 27, no. 4, pp. 820825, 2006.

[51] Z. Arsova-Sarafinovska, N. Matevska, A. Eken et al., "Glutathione peroxidase 1 (GPX1) genetic polymorphism, erythrocyte GPX activity, and prostate cancer risk," International Urology and Nephrology, vol. 41, no. 1, pp. 63-70, 2009.

[52] O. Raaschou-Nielsen, M. Sørensen, R. D. Hansen et al., "GPX1 Pro198Leu polymorphism, interactions with smoking and alcohol consumption, and risk for lung cancer," Cancer Letters, vol. 247, no. 2, pp. 293-300, 2007.

[53] Y. Ichimura, T. Habuchi, N. Tsuchiya et al., "Increased risk of bladder cancer associated with a glutathione peroxidase 1 codon 198 variant," The Journal of Urology, vol. 172, no. 2, pp. 728-732, 2004.

[54] M. D. Maines, "Heme oxygenase: function, multiplicity, regulatory mechanisms, and clinical applications," FASEB Journal, vol. 2, no. 10, pp. 2557-2568, 1988.

[55] S. M. Keyse and R. M. Tyrrell, "Heme oxygenase is the major 32$\mathrm{kDa}$ stress protein induced in human skin fibroblasts by UVA radiation, hydrogen peroxide, and sodium arsenite," Proceedings of the National Academy of Sciences of the United States of America, vol. 86, no. 1, pp. 99-103, 1989.

[56] S. W. Ryter and A. M. K. Choi, "Heme oxygenase-1: redox regulation of a stress protein in lung and cell culture models," Antioxidants and Redox Signaling, vol. 7, no. 1-2, pp. 80-91, 2005.

[57] A. Prawan, J. K. Kundu, and Y.-J. Surh, "Molecular basis of heme oxygenase-1 induction: implications for chemoprevention and chemoprotection," Antioxidants and Redox Signaling, vol. 7, no. 11-12, pp. 1688-1703, 2005.

[58] A. L. Furfaro, N. Traverso, C. Domenicotti et al., “The Nrf2/HO1 axis in cancer cell growth and chemoresistance," Oxidative Medicine and Cellular Longevity, vol. 2016, Article ID 1958174, 14 pages, 2016.

[59] A. Jozkowicz, H. Was, and J. Dulak, "Heme oxygenase-1 in tumors: is it a false friend?" Antioxidants and Redox Signaling, vol. 9, no. 12, pp. 2099-2117, 2007.

[60] H. Was, T. Cichon, R. Smolarczyk et al., "Overexpression of heme oxygenase- 1 in murine melanoma: increased proliferation and viability of tumor cells, decreased survival of mice," American Journal of Pathology, vol. 169, no. 6, pp. 2181-2198, 2006. 
[61] J.-R. Tsai, H.-M. Wang, P.-L. Liu et al., "High expression of heme oxygenase- 1 is associated with tumor invasiveness and poor clinical outcome in non-small cell lung cancer patients," Cellular Oncology, vol. 35, no. 6, pp. 461-471, 2012.

[62] M. Hill, V. Pereira, C. Chauveau et al., "Heme oxygenase-1 inhibits rat and human breast cancer cell proliferation: mutual cross inhibition with indoleamine 2,3-dioxygenase," The FASEB Journal, vol. 19, no. 14, pp. 1957-1968, 2005.

[63] C.-Y. Chao, C.-K. Lii, Y.-T. Hsu et al., "Induction of heme oxygenase-1 and inhibition of TPA-induced matrix metalloproteinase- 9 expression by andrographolide in MCF-7 human breast cancer cells," Carcinogenesis, vol. 34, no. 8, pp. 1843-1851, 2013.

[64] B. Wegiel, Z. Nemeth, M. Correa-Costa, A. C. Bulmer, and L. E. Otterbein, "Heme oxygenase-1: a metabolic nike," Antioxidants and Redox Signaling, vol. 20, no. 11, pp. 1709-1722, 2014.

[65] D. Tibullo, I. Barbagallo, C. Giallongo et al., "Heme oxygenase1 nuclear translocation regulates bortezomib-induced cytotoxicity and mediates genomic instability in myeloma cells," Oncotarget, vol. 7, no. 20, pp. 28868-28880, 2016.

[66] D. Tibullo, I. Barbagallo, C. Giallongo et al., "Nuclear translocation of Heme oxygenase-1 confers resistance to imatinib in chronic myeloid leukemia cells," Current Pharmaceutical Design, vol. 19, no. 15, pp. 2765-2770, 2013.

[67] O. W. Griffith, "Mechanism of action, metabolism, and toxicity of buthionine sulfoximine and its higher homologs, potent inhibitors of glutathione synthesis," Journal of Biological Chemistry, vol. 257, no. 22, pp. 13704-13712, 1982.

[68] G. T. Wondrak, "Redox-directed cancer therapeutics: molecular mechanisms and opportunities," Antioxidants and Redox Signaling, vol. 11, no. 12, pp. 3013-3069, 2009.

[69] B. Marengo, C. De Ciucis, D. Verzola et al., "Mechanisms of BSO (L-buthionine-S,R-sulfoximine)-induced cytotoxic effects in neuroblastoma," Free Radical Biology and Medicine, vol. 44, no. 3, pp. 474-482, 2008.

[70] B. Marengo, E. Balbis, S. Patriarca et al., "GSH loss per se does not affect neuroblastoma survival and is not genotoxic," International Journal of Oncology, vol. 32, no. 1, pp. 121-127, 2008.

[71] B. Marengo, L. Raffaghello, V. Pistoia et al., "Reactive oxygen species: biological stimuli of neuroblastoma cell response," Cancer Letters, vol. 228, no. 1-2, pp. 111-116, 2005.

[72] C. Domenicotti, B. Marengo, M. Nitti et al., "A novel role of protein kinase $\mathrm{C}-\delta$ in cell signaling triggered by glutathione depletion," Biochemical Pharmacology, vol. 66, no. 8, pp. 15211526, 2003.

[73] P. J. O’Dwyer, T. C. Hamilton, F. P. LaCreta et al., "Phase I trial of buthionine sulfoximine in combination with melphalan in patients with cancer," Journal of Clinical Oncology, vol. 14, no. 1, pp. 249-256, 1996.

[74] N. Sata, H. Stumpe-Klonowski, B. Han, D. Haüssinger, and C. Niederau, "Menadione induces both necrosis and apoptosis in rat pancreatic acinar AR4-2J cells," Free Radical Biology and Medicine, vol. 23, no. 6, pp. 844-850, 1997.

[75] M. Hallak, T. Win, O. Shpilberg et al., "The anti-leukaemic activity of novel synthetic naphthoquinones against acute myeloid leukaemia: induction of cell death via the triggering of multiple signalling pathways," British Journal of Haematology, vol. 147, no. 4, pp. 459-470, 2009.

[76] K. A. Margolin, S. A. Akman, L. A. Leong et al., "Phase I study of mitomycin C and menadione in advanced solid tumors," Cancer Chemotherapy and Pharmacology, vol. 36, no. 4, pp. 293-298, 1995.
[77] M. Tetef, K. Margolin, C. Ahn et al., "Mitomycin C and menadione for the treatment of lung cancer: a phase II trial," Investigational New Drugs, vol. 13, no. 2, pp. 157-162, 1995.

[78] K. Dvorakova, C. M. Payne, M. E. Tome, M. M. Briehl, T. McClure, and R. T. Dorr, "Induction of oxidative stress and apoptosis in myeloma cells by the aziridine-containing agent imexon," Biochemical Pharmacology, vol. 60, no. 6, pp. 749-758, 2000.

[79] A. F. Baker, T. Landowski, R. Dorr et al., "The antitumor agent imexon activates antioxidant gene expression: evidence for an oxidative stress response," Clinical Cancer Research, vol. 13, no. 11, pp. 3388-3394, 2007.

[80] S. Moulder, N. Dhillon, C. Ng et al., "A phase I trial of imexon, a pro-oxidant, in combination with docetaxel for the treatment of patients with advanced breast, non-small cell lung and prostate cancer," Investigational New Drugs, vol. 28, no. 5, pp. 634-640, 2010.

[81] S. J. Cohen, M. M. Zalupski, M. R. Modiano et al., "A phase I study of imexon plus gemcitabine as first-line therapy for advanced pancreatic cancer," Cancer Chemotherapy and Pharmacology, vol. 66, no. 2, pp. 287-294, 2010.

[82] P. M. Barr, T. P. Miller, J. W. Friedberg et al., "Phase 2 study of imexon, a prooxidant molecule, in relapsed and refractory Bcell non-Hodgkin lymphoma," Blood, vol. 124, no. 8, pp. 12591265, 2014.

[83] F. R. Kona, D. Buac, and A. M. Burger, "Disulfiram, and disulfiram derivatives as novel potential anticancer drugs targeting the ubiquitin-proteasome system in both preclinical and clinical studies," Current Cancer Drug Targets, vol. 11, no. 3, pp. 338-346, 2011.

[84] J. Zha, F. Chen, H. Dong et al., "Disulfiram targeting lymphoid malignant cell lines via ROS-JNK activation as well as Nrf2 and NF-kB pathway inhibition," Journal of Translational Medicine, vol. 12, no. 1, article 163, 2014.

[85] A. L. Furfaro, S. Piras, M. Passalacqua et al., "HO-1 upregulation: a key point in high-risk neuroblastoma resistance to bortezomib," Biochimica et Biophysica Acta (BBA)-Molecular Basis of Disease, vol. 1842, no. 4, pp. 613-622, 2014.

[86] T. Hideshima, P. Richardson, D. Chauhan et al., "The proteasome inhibitor PS-341 inhibits growth, induces apoptosis, and overcomes drug resistance in human multiple myeloma cells," Cancer Research, vol. 61, no. 7, pp. 3071-3076, 2001.

[87] M. H. Ma, H. H. Yang, K. Parker et al., "The proteasome inhibitor PS-341 markedly enhances sensitivity of multiple myeloma tumor cells to chemotherapeutic agents," Clinical Cancer Research, vol. 9, no. 3, pp. 1136-1144, 2003.

[88] S. Faderl, K. Rai, J. Gribben et al., "Phase II study of singleagent bortezomib for the treatment of patients with fludarabinerefractory B-cell chronic lymphocytic leukemia," Cancer, vol. 107, no. 5, pp. 916-924, 2006.

[89] L. M. Staudt, "Gene expression profiling of lymphoid malignancies," Annual Review of Medicine, vol. 53, pp. 303-318, 2002.

[90] P. G. Richardson, B. Barlogie, J. Berenson et al., "A phase 2 study of Bortezomib in relapsed, refractory myeloma," The New England Journal of Medicine, vol. 348, no. 26, pp. 2609-2617, 2003.

[91] D. M. Townsend, C. J. Pazoles, and K. D. Tew, "NOV-002, a mimetic of glutathione disulfide," Expert Opinion on Investigational Drugs, vol. 17, no. 7, pp. 1075-1083, 2008.

[92] P. Fidias and S. Novello, "Strategies for prolonged therapy in patients with advanced non-small-cell lung cancer," Journal of Clinical Oncology, vol. 28, no. 34, pp. 5116-5123, 2010. 
[93] A. J. Montero, C. M. Diaz-Montero, Y. E. Deutsch et al., "Phase 2 study of neoadjuvant treatment with NOV-002 in combination with doxorubicin and cyclophosphamide followed by docetaxel in patients with HER-2 negative clinical stage II-IIIc breast cancer," Breast Cancer Research and Treatment, vol. 132, no. 1, pp. 215-223, 2012.

[94] A. Raza, N. Galili, S. Smith et al., "Phase 1 multicenter doseescalation study of ezatiostat hydrochloride (TLK199 tablets), a novel glutathione analog prodrug, in patients with myelodysplastic syndrome," Blood, vol. 113, no. 26, pp. 6533-6540, 2009.

[95] A. F. Baker, T. Dragovich, W. R. Tate et al., “The antitumor thioredoxin-1 inhibitor PX-12 (1-methylpropyl 2-imidazolyl disulfide) decreases thioredoxin-1 and VEGF levels in cancer patient plasma," Journal of Laboratory and Clinical Medicine, vol. 147, no. 2, pp. 83-90, 2006.

[96] G.-Z. Li, H.-F. Liang, B. Liao et al., "Px-12 inhibits the growth of hepatocelluar carcinoma by inducing S-phase arrest, ROSdependent apoptosis and enhances 5-FU cytotoxicity," American Journal of Translational Research, vol. 7, no. 9, pp. 1528-1540, 2015.

[97] R. K. Ramanathan, M. Fakih, S. Mani et al., "Phase I and pharmacokinetic study of the novel redox-active agent, motexafin gadolinium, with concurrent radiation therapy in patients with locally advanced pancreatic or biliary cancers," Cancer Chemotherapy and Pharmacology, vol. 57, no. 4, pp. 465-474, 2006.

[98] E. Boven, M. Verschraagen, T. M. Hulscher et al., "BNP7787, a novel protector against platinum-related toxicities, does not affect the efficacy of cisplatin or carboplatin in human tumour xenografts," European Journal of Cancer, vol. 38, no. 8, pp. 11481156, 2002.

[99] F. H. Hausheer, D. Shanmugarajah, B. D. Leverett et al., "Mechanistic study of BNP7787-mediated cisplatin nephroprotection: modulation of gamma-glutamyl transpeptidase," Cancer Chemotherapy and Pharmacology, vol. 65, no. 5, pp. 941-951, 2010.

[100] R. J. Amato, J. Jac, and J. Hernandez-Mcclain, "Motexafin gadolinium for the treatment of metastatic renal cell carcinoma: phase II study results," Clinical Genitourinary Cancer, vol. 6, no. 2, pp. 73-78, 2008.

[101] T. S. Lin, L. Naumovski, P. S. Lecane et al., "Effects of motexafin gadolinium in a phase II trial in refractory chronic lymphocytic leukemia," Leukemia and Lymphoma, vol. 50, no. 12, pp. 19771982, 2009.

[102] M. P. Mehta, P. Rodrigus, C. H. J. Terhaard et al., "Survival and neurologic outcomes in a randomized trial of motexafin gadolinium and whole-brain radiation therapy in brain metastases," Journal of Clinical Oncology, vol. 21, no. 13, pp. 2529-2536, 2003.

[103] C. Robert, B. Karaszewska, J. Schachter et al., "Improved overall survival in melanoma with combined dabrafenib and trametinib," The New England Journal of Medicine, vol. 372, no. 1, pp. 30-39, 2015.

[104] T. Troiani, L. Vecchione, E. Martinelli et al., "Intrinsic resistance to selumetinib, a selective inhibitor of MEK1/2, by cAMPdependent protein kinase A activation in human lung and colorectal cancer cells," British Journal of Cancer, vol. 106, no. 10, pp. 1648-1659, 2012.

[105] J. Farley, W. E. Brady, V. Vathipadiekal et al., "Selumetinib in women with recurrent low-grade serous carcinoma of the ovary or peritoneum: an open-label, single-arm, phase 2 study," The Lancet Oncology, vol. 14, no. 2, pp. 134-140, 2013.
[106] A. L. Ho, R. K. Grewal, R. Leboeuf et al., "Selumetinibenhanced radioiodine uptake in advanced thyroid cancer," The New England Journal of Medicine, vol. 368, no. 7, pp. 623-632, 2013.

[107] K. Horgan, E. Cooke, M. B. Hallett, and R. E. Mansel, "Inhibition of protein kinase $\mathrm{C}$ mediated signal transduction by tamoxifen. Importance for antitumour activity," Biochemical Pharmacology, vol. 35, no. 24, pp. 4463-4465, 1986.

[108] W. T. Couldwell, M. H. Weiss, C. M. DeGiorgio et al., "Clinical and radiographic response in a minority of patients with recurrent malignant gliomas treated with high-dose tamoxifen," Neurosurgery, vol. 32, no. 3, pp. 485-490, 1993.

[109] P. A. Tang, G. Roldan, P. M. A. Brasher et al., "A phase II study of carboplatin and chronic high-dose tamoxifen in patients with recurrent malignant glioma," Journal of Neuro-Oncology, vol. 78, no. 3, pp. 311-316, 2006.

[110] V. C. Jordan, "Molecular mechanisms of antiestrogen action in breast cancer," Breast Cancer Research and Treatment, vol. 31, no. 1, pp. 41-52, 1994.

[111] S. A. Nazarali and S. A. Narod, "Tamoxifen for women at high risk of breast cancer," Breast Cancer: Targets and Therapy, vol. 6, pp. 29-36, 2014.

[112] J. J. Gills and P. A. Dennis, "Perifosine: update on a novel Akt inhibitor," Current Oncology Reports, vol. 11, no. 2, pp. 102-110, 2009.

[113] L. Van Ummersen, K. Binger, J. Volkman et al., "A phase I trial of perifosine (NSC 639966) on a loading dose/maintenance dose schedule in patients with advanced cancer," Clinical Cancer Research, vol. 10, no. 22, pp. 7450-7456, 2004.

[114] S. R. Vink, J. H. M. Schellens, J. H. Beijnen et al., "Phase I and pharmacokinetic study of combined treatment with perifosine and radiation in patients with advanced solid tumours," Radiotherapy and Oncology, vol. 80, no. 2, pp. 207-213, 2006.

[115] I. M. Ghobrial, A. Roccaro, F. Hong et al., "Clinical and translational studies of a phase II trial of the novel oral Akt inhibitor perifosine in relapsed or relapsed/refractory Waldenström's macroglobulinemia," Clinical Cancer Research, vol. 16, no. 3, pp. 1033-1041, 2010.

[116] P. G. Richardson, J. Wolf, A. Jakubowiak et al., "Perifosine plus bortezomib and dexamethasone in patients with relapsed/refractory multiple myeloma previously treated with bortezomib: results of a multicenter phase I/II trial," Journal of Clinical Oncology, vol. 29, no. 32, pp. 4243-4249, 2011.

[117] C. K. Weber, S. Liptay, T. Wirth, G. Adler, and R. M. Schmid, "Suppression of NF- $\kappa$ B activity by sulfasalazine is mediated by direct inhibition of I $\kappa \mathrm{B}$ kinases $\alpha$ and $\beta$," Gastroenterology, vol. 119, no. 5, pp. 1209-1218, 2000.

[118] M.-Z. Ma, G. Chen, P. Wang et al., "Xc' inhibitor sulfasalazine sensitizes colorectal cancer to cisplatin by a GSH-dependent mechanism," Cancer Letters, vol. 368, no. 1, pp. 88-96, 2015.

[119] W. A. Chow, C. Jiang, and M. Guan, "Anti-HIV drugs for cancer therapeutics: back to the future?" The Lancet Oncology, vol. 10, no. 1, pp. 61-71, 2009.

[120] A. C. Hoover, M. M. Milhem, C. M. Anderson et al., "Efficacy of nelfinavir as monotherapy in refractory adenoid cystic carcinoma: results of a phase II clinical trial," Head and Neck, vol. 37, no. 5, pp. 722-726, 2015.

[121] T. B. Brunner, M. Geiger, G. G. Grabenbauer et al., "Phase I trial of the human immunodeficiency virus protease inhibitor nelfinavir and chemoradiation for locally advanced pancreatic cancer," Journal of Clinical Oncology, vol. 26, no. 16, pp. 26992706, 2008. 
[122] R. Rengan, R. Mick, D. Pryma et al., "A phase I trial of the HIV protease inhibitor nelfinavir with concurrent chemoradiotherapy for unresectable stage IIIA/IIIB non-small cell lung cancer: a report of toxicities and clinical response," Journal of Thoracic Oncology, vol. 7, no. 4, pp. 709-715, 2012.

[123] S. Ackermann, M. W. Beckmann, F. Thiel, and T. Bogenrieder, "Topotecan in cervical cancer," International Journal of Gynecological Cancer, vol. 17, no. 6, pp. 1215-1223, 2007.

[124] D. K. Armstrong, M. A. Bookman, W. McGuire, R. E. Bristow, and J. M. Schilder, "A phase I study of paclitaxel, topotecan, cisplatin and Filgrastim in patients with newly diagnosed advanced ovarian epithelial malignancies: a Gynecologic Oncology Group study," Gynecologic Oncology, vol. 105, no. 3, pp. 667-671, 2007.

[125] J. L. Marshall, S. G. Eisenberg, M. D. Johnson et al., "A phase II trial of ISIS 3521 in patients with metastatic colorectal cancer," Clinical Colorectal Cancer, vol. 4, no. 4, pp. 268-274, 2004.

[126] A. W. Tolcher, L. Reyno, P. M. Venner et al., "A randomized Phase II and pharmacokinetic study of the antisense oligonucleotides ISIS 3521 and ISIS 5132 in patients with hormonerefractory prostate cancer," Clinical Cancer Research, vol. 8, no. 8, pp. 2530-2535, 2002.

[127] S. Rao, D. Watkins, D. Cunningham et al., "Phase II study of ISIS 3521, an antisense oligodeoxynucleotide to protein kinase $\mathrm{C}$ alpha, in patients with previously treated low-grade nonHodgkin's lymphoma," Annals of Oncology, vol. 15, no. 9, pp. 1413-1418, 2004.

[128] D. Fabbro, S. Ruetz, S. Bodis et al., "PKC412-a protein kinase inhibitor with a broad therapeutic potential," Anti-Cancer Drug Design, vol. 15, no. 1, pp. 17-28, 2000.

[129] M. J. Millward, C. House, D. Bowtell et al., "The multikinase inhibitor midostaurin (PKC412A) lacks activity in metastatic melanoma: a phase IIA clinical and biologic study," British Journal of Cancer, vol. 95, no. 7, pp. 829-834, 2006.

[130] T. A. Yap, L. Yan, A. Patnaik et al., "First-in-man clinical trial of the oral pan-AKT inhibitor MK-206 in patients with advanced solid tumors," Journal of Clinical Oncology, vol. 29, no. 35, pp. 4688-4695, 2011.

[131] M. A. Smith, R. Gorlick, E. A. Kolb et al., "Initial testing of JNJ-26854165 (Serdemetan) by the pediatric preclinical testing program," Pediatric Blood and Cancer, vol. 59, no. 2, pp. 329-332, 2012.

[132] K. K. Hoe, C. S. Verma, and D. P. Lane, "Drugging the p53 pathway: understanding the route to clinical efficacy," Nature Reviews Drug Discovery, vol. 13, no. 3, pp. 217-236, 2014.

[133] J. M. R. Lambert, P. Gorzov, D. B. Veprintsev et al., "PRIMA-1 reactivates mutant $\mathrm{p} 53$ by covalent binding to the core domain," Cancer Cell, vol. 15, no. 5, pp. 376-388, 2009.

[134] Y. Rew and D. Sun, "Discovery of a small molecule MDM2 inhibitor (AMG 232) for treating cancer," Journal of Medicinal Chemistry, vol. 57, no. 15, pp. 6332-6341, 2014.

[135] L. Zhang, K. Wang, Y. Lei, Q. Li, E. C. Nice, and C. Huang, "Redox signaling: potential arbitrator of autophagy and apoptosis in therapeutic response," Free Radical Biology and Medicine, vol. 89, pp. 452-465, 2015.

[136] G. E. N. Kass, S. K. Duddy, and S. Orrenius, "Activation of hepatocyte protein kinase C by redox-cycling quinones," Biochemical Journal, vol. 260, no. 2, pp. 499-507, 1989.

[137] X. Sun, F. Wu, R. Datta, S. Kharbanda, and D. Kufe, "Interaction between protein kinase $\mathrm{C} \delta$ and the c-Abl tyrosine kinase in the cellular response to oxidative stress," The Journal of Biological Chemistry, vol. 275, no. 11, pp. 7470-7473, 2000.
[138] R. Gopalakrishna and W. B. Anderson, "Ca2+-and phospholipid-independent activation of protein kinase $C$ by selective oxidative modification of the regulatory domain," Proceedings of the National Academy of Sciences of the United States of America, vol. 86, no. 17, pp. 6758-6762, 1989.

[139] M. A. Pronzato, D. Cottalasso, C. Domenicotti et al., "Effects of CC14 poisoning on metabolism of dolichol in RAT liver microsomes and golgi apparatus," Free Radical Research, vol. 11, no. 4-5, pp. 267-277, 1990.

[140] M. A. Pronzato, C. Domenicotti, F. Biasi et al., "Inactivation of hepatocyte protein kinase $\mathrm{C}$ by carbon tetrachloride: involvement of drug's metabolic activation and prooxidant effect," Biochemical and Biophysical Research Communications, vol. 171, no. 3, pp. 1353-1360, 1990.

[141] C. Domenicotti, D. Paola, A. Vitali et al., "Mechanisms of inactivation of hepatocyte protein kinase $\mathrm{C}$ isoforms following acute ethanol treatment," Free Radical Biology and Medicine, vol. 25, no. 4-5, pp. 529-535, 1998.

[142] C. Domenicotti, D. Paola, A. Vitali et al., "Ethanol-induced effects on expression level, activity, and distribution of protein kinase C isoforms in rat liver Golgi apparatus," ChemicoBiological Interactions, vol. 114, no. 1-2, pp. 33-43, 1998.

[143] C. E. Antal, A. M. Hudson, E. Kang et al., "Cancer-associated protein kinase $\mathrm{C}$ mutations reveal kinase's role as tumor suppressor," Cell, vol. 160, no. 3, pp. 489-502, 2015.

[144] L. Langzam, R. Koren, R. Gal et al., "Patterns of protein kinase C isoenzyme expression in transitional cell carcinoma of bladder relation to degree of malignancy," American Journal of Clinical Pathology, vol. 116, no. 3, pp. 377-385, 2001.

[145] G. W. Neill, L. R. Ghali, J. L. Green, M. S. Ikram, M. P. Philpott, and A. G. Quinn, "Loss of protein kinase $\mathrm{C} \alpha$ expression may enhance the tumorigenic potential of Glil in basal cell carcinoma," Cancer Research, vol. 63, no. 15, pp. 4692-4697, 2003.

[146] H. Oster and M. Leitges, "Protein kinase $\mathrm{C} \alpha$ but not PKC $\zeta$ suppresses intestinal tumor formation in ApcMin/+ mice," Cancer Research, vol. 66, no. 14, pp. 6955-6963, 2006.

[147] Y. Gökmen-Polar, N. R. Murray, M. A. Velasco, Z. Gatalica, and A. P. Fields, "Elevated protein kinase $\mathrm{C} \beta \mathrm{II}$ is an early promotive event in colon carcinogenesis," Cancer Research, vol. 61, no. 4, pp. 1375-1381, 2001.

[148] W. Yu, N. R. Murray, C. Weems et al., "Role of cyclooxygenase 2 in protein kinase $\mathrm{C} \beta \mathrm{II}-$ mediated colon carcinogenesis," Journal of Biological Chemistry, vol. 278, no. 13, pp. 11167-11174, 2003.

[149] E. Migliaccio, M. Giogio, S. Mele et al., "The p66 $6^{\text {shc }}$ adaptor protein controls oxidative stress response and life span in mammals," Nature, vol. 402, no. 6759, pp. 309-313, 1999.

[150] J. Wang, M. Shao, M. Liu et al., "PKC $\alpha$ promotes generation of reactive oxygen species via DUOX2 in hepatocellular carcinoma," Biochemical and Biophysical Research Communications, vol. 463, no. 4, pp. 839-845, 2015.

[151] M. Nitti, A. L. Furfaro, C. Cevasco et al., "PKC delta and NADPH oxidase in retinoic acid-induced neuroblastoma cell differentiation," Cellular Signalling, vol. 22, no. 5, pp. 828-835, 2010.

[152] D. N. Jackson and D. A. Foster, "The enigmatic protein kinase $\mathrm{C} \delta$ : complex roles in cell proliferation and survival," The FASEB Journal, vol. 18, no. 6, pp. 627-636, 2004.

[153] N. A. Riobo, G. M. Haines, and C. P. Emerson Jr., "Protein kinase $\mathrm{C}-\delta$ and mitogen-activated protein/extracellular signalregulated kinase-1 control GLI activation in hedgehog signaling," Cancer Research, vol. 66, no. 2, pp. 839-845, 2006. 
[154] E. M. Griner and M. G. Kazanietz, "Protein kinase C and other diacylglycerol effectors in cancer," Nature Reviews Cancer, vol. 7, no. 4, pp. 281-294, 2007.

[155] S. M. Nabha, S. Glaros, M. Hong et al., "Upregulation of PKC- $\delta$ contributes to antiestrogen resistance in mammary tumor cells," Oncogene, vol. 24, no. 19, pp. 3166-3176, 2005.

[156] B. Marengo, C. de Ciucis, R. Ricciarelli et al., "PKC $\delta$ sensitizes neuroblastoma cells to L-buthionine-sulfoximine and etoposide inducing reactive oxygen species overproduction and DNA damage," PLoS ONE, vol. 6, no. 2, article e14661, 2011.

[157] A. R. M. Ruhul Amin, T. Senga, M. L. Oo, A. A. Thant, and M. Hamaguchi, "Secretion of matrix metalloproteinase- 9 by the proinflammatory cytokine, IL-1 $\beta$ : a role for the dual signalling pathways, Akt and Erk," Genes to Cells, vol. 8, no. 6, pp. 515-523, 2003.

[158] L. Chang, P. H. Graham, J. Hao et al., "Acquisition of epithelialmesenchymal transition and cancer stem cell phenotypes is associated with activation of the PI3K/Akt/mTOR pathway in prostate cancer radioresistance," Cell Death and Disease, vol. 4, no. 10, article e875, 2013.

[159] S. S. Kang, T. Kwon, D. Y. Kwon, and S. I. Do, "Akt protein kinase enhances human telomerase activity through phosphorylation of telomerase reverse transcriptase subunit," Journal of Biological Chemistry, vol. 274, no. 19, pp. 13085-13090, 1999.

[160] G. Leonarduzzi, B. Sottero, G. Testa, F. Biasi, and G. Poli, "New insights into redox-modulated cell signaling," Current Pharmaceutical Design, vol. 17, no. 36, pp. 3994-4006, 2011.

[161] M. Los, S. Maddika, B. Erb, and K. Schulze-Osthoff, "Switching Akt: from survival signaling to deadly response," BioEssays, vol. 31, no. 5, pp. 492-495, 2009.

[162] J. Xu, W. Tian, X. Ma et al., "The molecular mechanism underlying morphine-induced akt activation: roles of protein phosphatases and reactive oxygen species," Cell Biochemistry and Biophysics, vol. 61, no. 2, pp. 303-311, 2011.

[163] N. R. Leslie, "The redox regulation of PI 3-kinase-dependent signaling," Antioxidants and Redox Signaling, vol. 8, no. 9-10, pp. 1765-1774, 2006.

[164] H. Ichijo, E. Nishida, K. Irie et al., "Induction of apoptosis by ASK1, a mammalian MAPKKK that activates SAPK/JNK and p38 signaling pathways," Science, vol. 275, no. 5296, pp. 90-94, 1997.

[165] E. H. Goldman, L. Chen, and H. Fu, "Activation of apoptosis signal-regulating kinase 1 by reactive oxygen species through dephosphorylation at serine 967 and 14-3-3 dissociation," Journal of Biological Chemistry, vol. 279, no. 11, pp. 10442-10449, 2004.

[166] M. Saitoh, H. Nishitoh, M. Fujii et al., "Mammalian thioredoxin is a direct inhibitor of apoptosis signal-regulating kinase (ASK) 1," The EMBO Journal, vol. 17, no. 9, pp. 2596-2606, 1998.

[167] T. M. Thornton and M. Rincon, "Non-classical p38 map kinase functions: cell cycle checkpoints and survival," International Journal of Biological Sciences, vol. 5, no. 1, pp. 44-52, 2009.

[168] L. Hui, L. Bakiri, A. Mairhorfer et al., "p38 $\alpha$ suppresses normal and cancer cell proliferation by antagonizing the JNK-c-Jun pathway," Nature Genetics, vol. 39, no. 6, pp. 741-749, 2007.

[169] J. J. Ventura, S. Tenbaum, E. Perdiguero et al., "p38 $\alpha$ MAP kinase is essential in lung stem and progenitor cell proliferation and differentiation," Nature Genetics, vol. 39, no. 6, pp. 750-758, 2007.

[170] M.-S. Kim, E.-J. Lee, H.-R. C. Kim, and A. Moon, "p38 kinase is a key signaling molecule for H-ras-induced cell motility and invasive phenotype in human breast epithelial cells," Cancer Research, vol. 63, no. 17, pp. 5454-5461, 2003.

[171] L. C. Platanias, "Map kinase signaling pathways and hematologic malignancies," Blood, vol. 101, no. 12, pp. 4667-4679, 2003.

[172] D. Halawani, R. Mondeh, L.-A. Stanton, and F. Beier, "p38 MAP kinase signaling is necessary for rat chondrosarcoma cell proliferation," Oncogene, vol. 23, no. 20, pp. 3726-3731, 2004.

[173] B. Marengo, C. G. De Ciucis, R. Ricciarelli et al., "P38MAPK inhibition: a new combined approach to reduce neuroblastoma resistance under etoposide treatment," Cell Death and Disease, vol. 4, article e589, 2013.

[174] X. Shi, Y. Zhang, J. Zheng, and J. Pan, "Reactive oxygen species in cancer stem cells," Antioxidants and Redox Signaling, vol. 16, no. 11, pp. 1215-1228, 2012.

[175] C. Cosentino, D. Grieco, and V. Costanzo, "ATM activates the pentose phosphate pathway promoting anti-oxidant defence and DNA repair," EMBO Journal, vol. 30, no. 3, pp. 546-555, 2011.

[176] H. Yin and J. Glass, "The phenotypic radiation resistance of CD44+/CD24(-or low) breast cancer cells is mediated through the enhanced activation of ATM signaling," PLoS ONE, vol. 6, no. 9, Article ID e24080, 2011.

[177] A. Molchadsky, N. Rivlin, R. Brosh, V. Rotter, and R. Sarig, "P53 is balancing development, differentiation and de-differentiation to assure cancer prevention," Carcinogenesis, vol. 31, no. 9, pp. 1501-1508, 2010.

[178] Y. Haupt, R. Maya, A. Kazaz, and M. Oren, "Mdm2 promotes the rapid degradation of p53," Nature, vol. 387, no. 6630, pp. 296299, 1997.

[179] A. M. Bode and Z. Dong, "Post-translational modification of p53 in tumorigenesis," Nature Reviews Cancer, vol. 4, no. 10, pp. 793-805, 2004.

[180] J.-P. Kruse and W. Gu, "Modes of p53 regulation," Cell, vol. 137, no. 4, pp. 609-622, 2009.

[181] K. Polyak, Y. Xia, J. L. Zweier, K. W. Kinzler, and B. Vogelstein, "A model for p53-induced apoptosis," Nature, vol. 389, no. 6648, pp. 300-305, 1997.

[182] A. Rivera and S. A. Maxwell, "The p53-induced gene-6 (proline oxidase) mediates apoptosis through a calcineurin-dependent pathway," Journal of Biological Chemistry, vol. 280, no. 32, pp. 29346-29354, 2005.

[183] A. A. Sablina, A. V. Budanov, G. V. Ilyinskaya, L. S. Agapova, J. E. Kravchenko, and P. M. Chumakov, "The antioxidant function of the p53 tumor suppressor," Nature Medicine, vol. 11, no. 12, pp. 1306-1313, 2005.

[184] D. Italiano, A. M. Lena, G. Melino, and E. Candi, "Identification of NCF2/p67phox as a novel p53 target gene," Cell Cycle, vol. 11, no. 24, pp. 4589-4596, 2012.

[185] K. H. Vousden and K. M. Ryan, "P53 and metabolism," Nature Reviews Cancer, vol. 9, no. 10, pp. 691-700, 2009.

[186] S. P. Hussain, P. Amstad, P. He et al., "p53-induced up-regulation of MnSOD and GPx but not catalase increases oxidative stress and apoptosis," Cancer Research, vol. 64, no. 7, pp. 2350-2356, 2004.

[187] S. Y. Nam and K. Sabapathy, "P53 promotes cellular survival in a context-dependent manner by directly inducing the expression of haeme-oxygenase-1," Oncogene, vol. 30, no. 44, pp. 44764486, 2011.

[188] K. Bensaad, A. Tsuruta, M. A. Selak et al., "TIGAR, a p53inducible regulator of glycolysis and apoptosis," Cell, vol. 126, no. 1, pp. 107-120, 2006. 
[189] C. Gorrini, I. S. Harris, and T. W. Mak, "Modulation of oxidative stress as an anticancer strategy," Nature Reviews Drug Discovery, vol. 12, no. 12, pp. 931-947, 2013.

[190] W. Hu, C. Zhang, R. Wu, Y. Sun, A. Levine, and Z. Feng, "Glutaminase 2, a novel p53 target gene regulating energy metabolism and antioxidant function," Proceedings of the National Academy of Sciences of the United States of America, vol. 107, no. 16, pp. 7455-7460, 2010.

[191] R. Hu, C. L. Saw, R. Yu, and A.-N. Kong, "Regulation of NF-E2-related factor 2 signaling for cancer chemoprevention: antioxidant coupled with antiinflammatory," Antioxidants and Redox Signaling, vol. 13, no. 11, pp. 1679-1698, 2010.

[192] N. Wakabayashi, S. L. Slocum, J. J. Skoko, S. Shin, and T. W. Kensler, "When NRF2 talks, who's listening?" Antioxidants and Redox Signaling, vol. 13, no. 11, pp. 1649-1663, 2010.

[193] C. J. Harvey, R. K. Thimmulappa, A. Singh et al., "Nrf2regulated glutathione recycling independent of biosynthesis is critical for cell survival during oxidative stress," Free Radical Biology and Medicine, vol. 46, no. 4, pp. 443-453, 2009.

[194] J. Nordberg and E. S. J. Arnér, "Reactive oxygen species, antioxidants, and the mammalian thioredoxin system," Free Radical Biology and Medicine, vol. 31, no. 11, pp. 1287-1312, 2001.

[195] B. Padmanabhan, K. I. Tong, T. Ohta et al., "Structural basis for defects of Keap1 activity provoked by its point mutations in lung cancer," Molecular Cell, vol. 21, no. 5, pp. 689-700, 2006.

[196] A. Singh, V. Misra, R. K. Thimmulappa et al., "Dysfunctional KEAP1-NRF2 interaction in non-small-cell lung cancer," PLoS Medicine, vol. 3, no. 10, article e420, 2006.

[197] T. Ohta, K. Iijima, M. Miyamoto et al., "Loss of Keap1 function activates Nrf2 and provides advantages for lung cancer cell growth," Cancer Research, vol. 68, no. 5, pp. 1303-1309, 2008.

[198] P. Nioi and T. Nguyen, "A mutation of Keap1 found in breast cancer impairs its ability to repress Nrf2 activity," Biochemical and Biophysical Research Communications, vol. 362, no. 4, pp. 816-821, 2007.

[199] T. Shibata, T. Ohta, K. I. Tong et al., "Cancer related mutations in NRF2 impair its recognition by Keap1-Cul3 E3 ligase and promote malignancy," Proceedings of the National Academy of Sciences of the United States of America, vol. 105, no. 36, pp. 13568-13573, 2008.

[200] S. Devarakonda, D. Morgensztern, and R. Govindan, "Genomic alterations in lung adenocarcinoma," The Lancet Oncology, vol. 16, no. 7, pp. e342-e351, 2015.

[201] E. S. J. Arnér and A. Holmgren, "Physiological functions of thioredoxin and thioredoxin reductase," European Journal of Biochemistry, vol. 267, no. 20, pp. 6102-6109, 2000.

[202] A. You, C.-W. Nam, N. Wakabayashi, M. Yamamoto, T. W. Kensler, and M.-K. Kwak, "Transcription factor Nrf2 maintains the basal expression of Mdm2: an implication of the regulation of p53 signaling by Nrf2," Archives of Biochemistry and Biophysics, vol. 507, no. 2, pp. 356-364, 2011.

[203] M. C. Jaramillo and D. D. Zhang, "The emerging role of the Nrf2-Keap1 signaling pathway in cancer," Genes and Development, vol. 27, no. 20, pp. 2179-2191, 2013.

[204] A. L. Furfaro, J. R. Z. MacAy, B. Marengo et al., "Resistance of neuroblastoma GI-ME-N cell line to glutathione depletion involves Nrf2 and heme oxygenase-1," Free Radical Biology and Medicine, vol. 52, no. 2, pp. 488-496, 2012.

[205] Z. J. Chen, "Ubiquitin signalling in the NF- $\kappa$ B pathway," Nature Cell Biology, vol. 7, no. 8, pp. 758-765, 2005.
[206] S. Miyamoto, "Nuclear initiated NF- $\kappa$ B signaling: NEMO and ATM take center stage," Cell Research, vol. 21, no. 1, pp. 116-130, 2011.

[207] M. J. Morgan and Z.-G. Liu, "Crosstalk of reactive oxygen species and NF- $\kappa \mathrm{B}$ signaling," Cell Research, vol. 21, no. 1, pp. 103-115, 2011.

[208] L. Flohé, S. Toppo, G. Cozza, and F. Ursini, "A comparison of thiol peroxidase mechanisms," Antioxidants and Redox Signaling, vol. 15, no. 3, pp. 763-780, 2011.

[209] F. Antunes and D. Han, "Redox regulation of NF- $\kappa$ B: from basic to clinical research," Antioxidants and Redox Signaling, vol. 11, no. 9, pp. 2055-2056, 2009.

[210] F. Wang, J. L. Yang, K. K. Yu et al., "Activation of the NF-kappaB pathway as a mechanism of alcohol enhanced progression and metastasis of human hepatocellular carcinoma," Molecular Cancer, vol. 14, no. 1, article 10, 2015.

[211] K. B. Myant, P. Cammareri, E. J. McGhee et al., "ROS production and NF- $\kappa \mathrm{B}$ activation triggered by RACl facilitate WNTdriven intestinal stem cell proliferation and colorectal cancer initiation," Cell Stem Cell, vol. 12, no. 6, pp. 761-773, 2013.

[212] J. Grosjean-Raillard, M. Tailler, L. Adès et al., "ATM mediates constitutive NF- $\kappa \mathrm{B}$ activation in high-risk myelodysplastic syndrome and acute myeloid leukemia," Oncogene, vol. 28, no. 8, pp. 1099-1109, 2009.

[213] R. R. Rosato, S. S. Kolla, S. K. Hock et al., "Histone deacetylase inhibitors activate NF- $\kappa \mathrm{B}$ in human leukemia cells through an ATM/NEMO-related pathway," The Journal of Biological Chemistry, vol. 285, no. 13, pp. 10064-10077, 2010.

[214] G. L. Wang, B.-H. Jiang, E. A. Rue, and G. L. Semenza, "Hypoxia-inducible factor 1 is a basic-helix-loop-helix-PAS heterodimer regulated by cellular $\mathrm{O} 2$ tension," Proceedings of the National Academy of Sciences of the United States of America, vol. 92, no. 12, pp. 5510-5514, 1995.

[215] P. J. Kallio, I. Pongratz, K. Gradin, J. McGuire, and L. Poellinger, "Activation of hypoxia-inducible factor $1 \alpha$ : posttranscriptional regulation and conformational change by recruitment of the Arnt transcription factor," Proceedings of the National Academy of Sciences of the United States of America, vol. 94, no. 11, pp. 5667-5672, 1997.

[216] J.-W. Kim, P. Gao, Y.-C. Liu, G. L. Semenza, and C. V. Dang, "Hypoxia-inducible factor 1 and dysregulated c-Myc cooperatively induce vascular endothelial growth factor and metabolic switches hexokinase 2 and pyruvate dehydrogenase kinase 1," Molecular and Cellular Biology, vol. 27, no. 21, pp. 7381-7393, 2007.

[217] G. L. Semenza, "Targeting HIF-1 for cancer therapy," Nature Reviews Cancer, vol. 3, no. 10, pp. 721-732, 2003.

[218] G. L. Semenza, "Defining the role of hypoxia-inducible factor 1 in cancer biology and therapeutics," Oncogene, vol. 29, no. 5, pp. 625-634, 2010.

[219] G. L. Semenza, "Regulation of cancer cell metabolism by hypoxia-inducible factor 1," Seminars in Cancer Biology, vol. 19, no. 1, pp. 12-16, 2009.

[220] S. Movafagh, S. Crook, and K. Vo, "Regulation of hypoxiainducible factor-1a by reactive oxygen species: new developments in an old debate," Journal of Cellular Biochemistry, vol. 116, no. 5, pp. 696-703, 2015.

[221] W. R. Wilson and M. P. Hay, "Targeting hypoxia in cancer therapy," Nature Reviews Cancer, vol. 11, no. 6, pp. 393-410, 2011.

[222] T. Ozben, "Oxidative stress and apoptosis: impact on cancer therapy," Journal of Pharmaceutical Sciences, vol. 96, no. 9, pp. 2181-2196, 2007. 
[223] M. F. Renschler, "The emerging role of reactive oxygen species in cancer therapy," European Journal of Cancer, vol. 40, no. 13, pp. 1934-1940, 2004.

[224] B. K. Samulitis, T. H. Landowski, and R. T. Dorr, "Correlates of imexon sensitivity in human multiple myeloma cell lines," Leukemia and Lymphoma, vol. 47, no. 1, pp. 97-109, 2006.

[225] K. Dvorakova, C. M. Payne, M. E. Tome et al., "Molecular and cellular characterization of imexon-resistant RPMI8226/I myeloma cells," Molecular Cancer Therapeutics, vol. 1, no. 3, pp. 185-195, 2002.

[226] D. Cen, D. Brayton, B. Shahandeh, F. L. Meyskens Jr., and P. J. Farmer, "Disulfiram facilitates intracellular $\mathrm{Cu}$ uptake and induces apoptosis in human melanoma cells," Journal of Medicinal Chemistry, vol. 47, no. 27, pp. 6914-6920, 2004.

[227] F.-T. Liu, S. G. Agrawal, J. G. Gribben et al., "Bortezomib blocks Bax degradation in malignant $B$ cells during treatment with TRAIL," Blood, vol. 111, no. 5, pp. 2797-2805, 2008.

[228] J. Hou, A. Cui, P. Song, H. Hua, T. Luo, and Y. Jiang, "Reactive oxygen species-mediated activation of the Srcepidermal growth factor receptor-Akt signaling cascade prevents bortezomib-induced apoptosis in hepatocellular carcinoma cells," Molecular Medicine Reports, vol. 11, no. 1, pp. 712718, 2015.

[229] A. J. Montero and J. Jassem, "Cellular redox pathways as a therapeutic target in the treatment of cancer," Drugs, vol. 71, no. 11, pp. 1385-1396, 2011.

[230] U. A. Matulonis, N. S. Horowitz, S. M. Campos et al., "Phase II study of carboplatin and pemetrexed for the treatment of platinum-sensitive recurrent ovarian cancer," Journal of Clinical Oncology, vol. 26, no. 35, pp. 5761-5766, 2008.

[231] D. M. Townsend and K. D. Tew, "Pharmacology of a mimetic of glutathione disulfide, NOV-002," Biomedicine and Pharmacotherapy, vol. 63, no. 2, pp. 75-78, 2009.

[232] D. Magda, P. Lecane, R. A. Miller et al., "Motexafin gadolinium disrupts zinc metabolism in human cancer cell lines," Cancer Research, vol. 65, no. 9, pp. 3837-3845, 2005.

[233] D. Magda and R. A. Miller, "Motexafin gadolinium: a novel redox active drug for cancer therapy," Seminars in Cancer Biology, vol. 16, no. 6, pp. 466-476, 2006. 


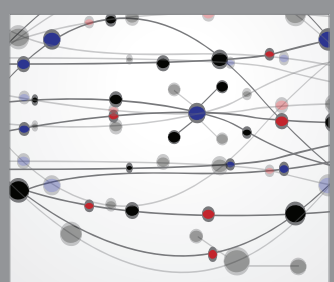

The Scientific World Journal
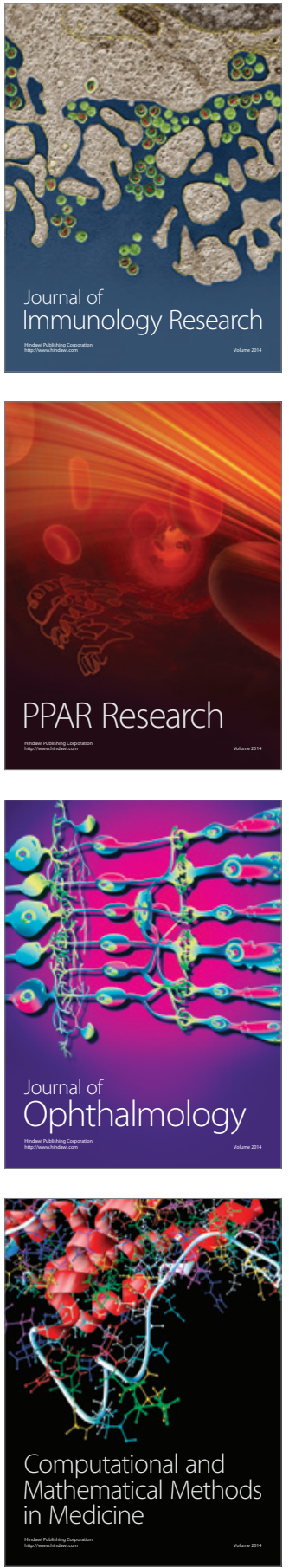

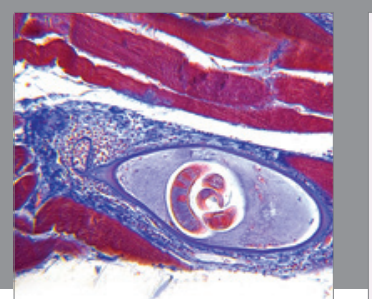

Gastroenterology Research and Practice

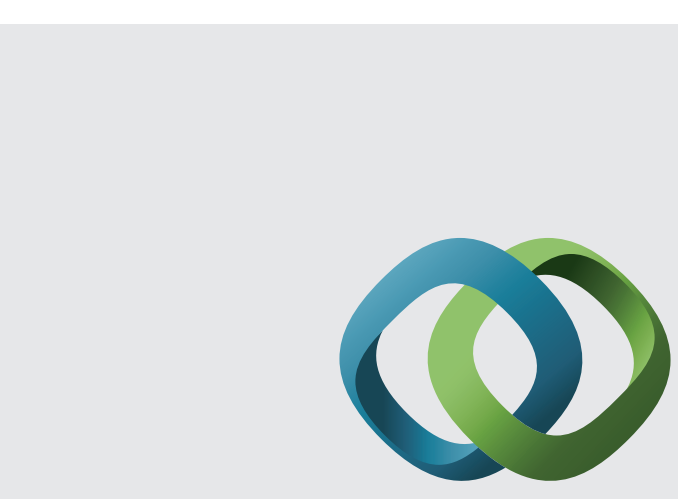

\section{Hindawi}

Submit your manuscripts at

http://www.hindawi.com
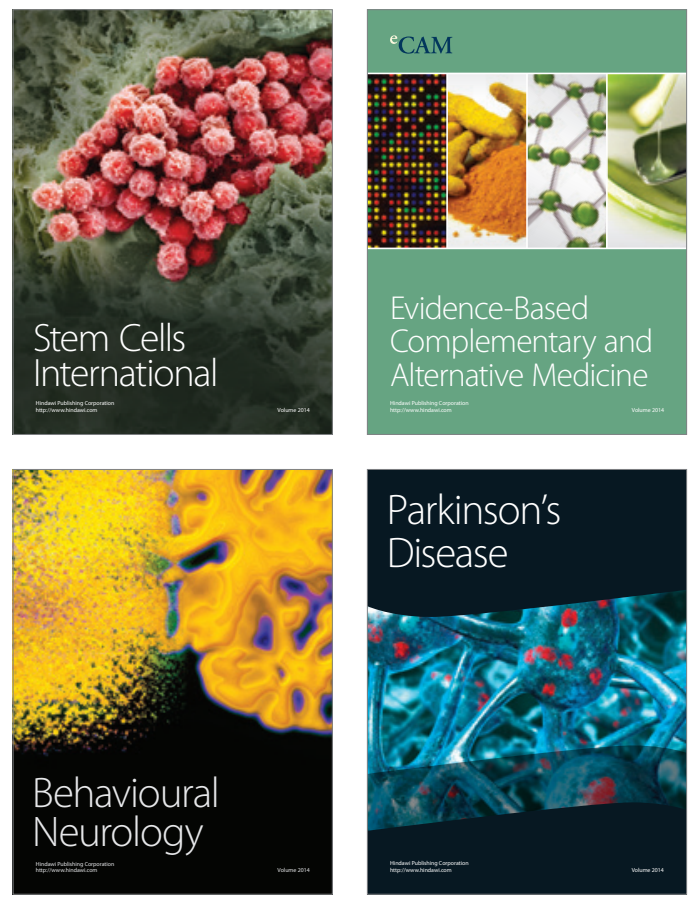
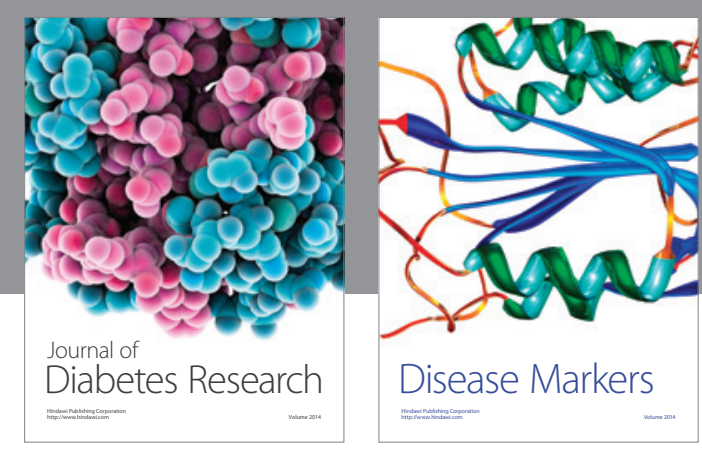

Disease Markers
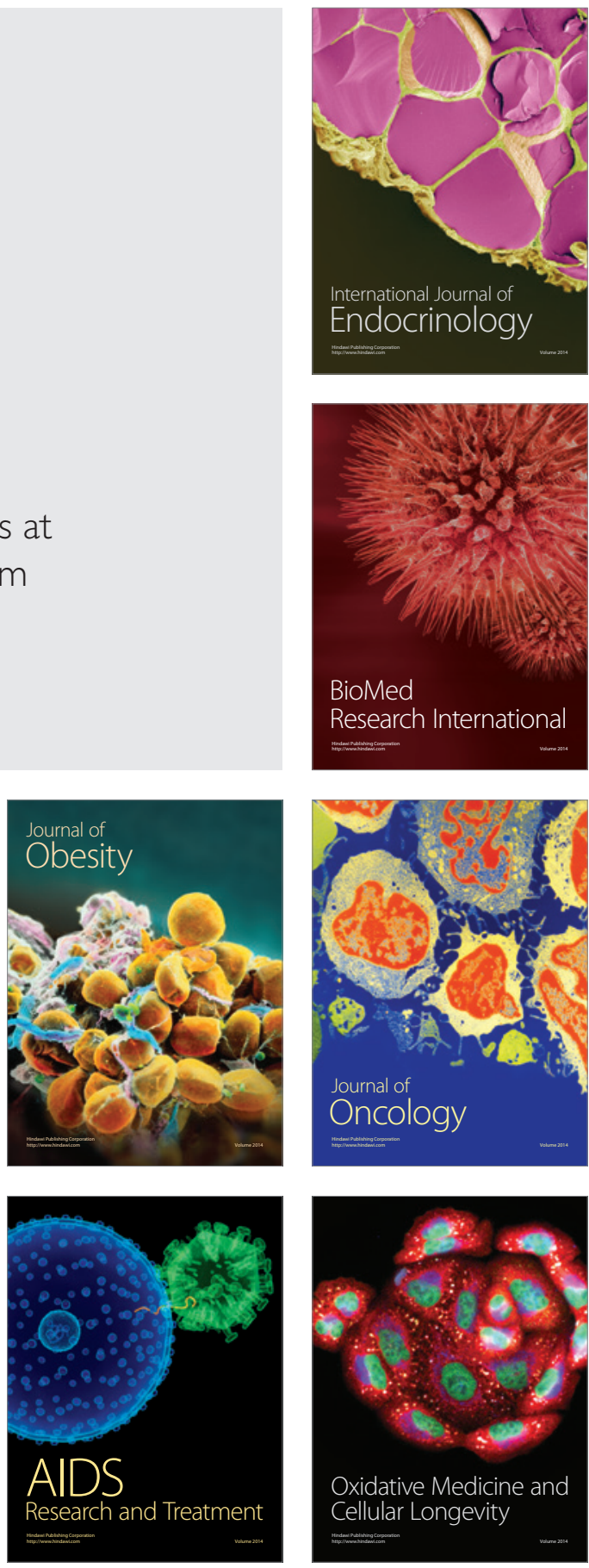